IZA DP No. 6032

\title{
Role Reversal in Global Finance
}

Eswar S. Prasad

October 2011 


\title{
Role Reversal in Global Finance
}

\author{
Eswar S. Prasad \\ Cornell University, Brookings Institution, \\ NBER and IZA
}

\section{Discussion Paper No. 6032 October 2011}

\author{
IZA \\ P.O. Box 7240 \\ 53072 Bonn \\ Germany \\ Phone: +49-228-3894-0 \\ Fax: +49-228-3894-180 \\ E-mail: iza@iza.org
}

\begin{abstract}
Any opinions expressed here are those of the author(s) and not those of IZA. Research published in this series may include views on policy, but the institute itself takes no institutional policy positions.

The Institute for the Study of Labor (IZA) in Bonn is a local and virtual international research center and a place of communication between science, politics and business. IZA is an independent nonprofit organization supported by Deutsche Post Foundation. The center is associated with the University of Bonn and offers a stimulating research environment through its international network, workshops and conferences, data service, project support, research visits and doctoral program. IZA engages in (i) original and internationally competitive research in all fields of labor economics, (ii) development of policy concepts, and (iii) dissemination of research results and concepts to the interested public.
\end{abstract}

IZA Discussion Papers often represent preliminary work and are circulated to encourage discussion. Citation of such a paper should account for its provisional character. A revised version may be available directly from the author. 


\section{ABSTRACT}

\section{Role Reversal in Global Finance*}

I document that emerging markets have cast off their "original sin" - their external liabilities are no longer dominated by foreign-currency debt and have instead shifted sharply towards direct investment and portfolio equity. Their external assets are increasingly concentrated in foreign exchange reserves held in advanced economy government bonds. Given the enormous and rising public debt burdens of reserve currency economies, this means that the long-term risk on emerging markets' external balance sheets is shifting to the asset side. However, emerging markets continue to look for more insurance against balance of payments crises, even as self-insurance through reserve accumulation itself becomes riskier. I propose a mechanism for global liquidity insurance that would meet emerging markets' demand for insurance with fewer domestic policy distortions while facilitating a quicker adjustment of global imbalances. I also argue that emerging markets have become less dependent on foreign finance and more resilient to capital flow volatility. The main risk that increasing financial openness poses for these economies is that capital flows exacerbate vulnerabilities arising from weak domestic policies and institutions.

JEL Classification: F3, F4

Keywords: emerging markets, international investment positions, structure of external assets and liabilities, foreign exchange reserves, global liquidity insurance

Corresponding author:

Eswar S. Prasad

Cornell University

Dyson School of Applied Economics and Management

440 Warren Hall

Ithaca, NY 14853

USA

E-mail: eswar.prasad@cornell.edu

\footnotetext{
* This paper was prepared for the 2011 Jackson Hole Symposium organized by the Federal Reserve Bank of Kansas City. I am grateful to Susan Collins, Andrew Karolyi, Don Kohn and M. Ayhan Kose for their detailed and thoughtful comments. I also thank participants at the Jackson Hole conference and numerous colleagues at Cornell and Brookings for helpful comments and discussions. Mengjie Ding, Karim Foda, Parul Sharma and especially Lei (Sandy) Ye provided excellent research assistance.
} 


\section{Introduction}

The global financial crisis has sparked a reconsideration of the role of unfettered capital flows in the new international economic order. Far from fulfilling their promises of boosting growth and helping to diversify risk, capital flows are now seen by some as a destructive force, causing crises that take down countries and scorch innocent bystanders in their wake. Yet, despite all the opprobrium directed at them, capital flows are resurgent once again. Many emerging markets in fact face the problem of plenty as their strong growth prospects fuel surges of inflows and create pressures on domestic inflation, asset prices and exchange rates.

In this paper, I first evaluate recent trends in global financial integration and examine whether the financial crisis has halted or reversed this process. Next, I examine the evolution of the structures of external balance sheets of the major advanced and emerging market economies and evaluate the implications for capital flows and vulnerability to external shocks. Third, I offer a proposal for global insurance that may help emerging markets obviate the domestic and collective costs of self-insurance through reserve accumulation. Fourth, I review the changing complexion of risks that capital account openness poses for emerging markets. ${ }^{2}$

The main points of the paper are as follows:

1. The financial crisis represented only a brief pause in the process of global financial integration. External balance sheets are expanding rapidly for virtually all major economies. Rising gross external asset and liability positions imply greater financial integration but also higher capital flow volatility due to currency fluctuations, portfolio rebalancing, and

\footnotetext{
${ }^{2}$ I use the IMF classification of advanced economies and emerging markets. Countries with per capita income of over $\$ 15,000$ in 2010 (at market exchange rates) are counted as advanced economies. The list changes only marginally when one uses purchasing power parity-adjusted exchange rates and an income threshold of about $\$ 18,000$ in 2010 (Hungary and Poland would then be classified as advanced). The 58 economies - 29 advanced and 29 emerging - included in the analysis sample account for about 90 percent of global GDP and are listed in the appendix. Switching economies like Hong Kong, Israel, Korea and Singapore to the emerging markets category only strengthens many of the empirical observations in this paper.
} 
greater exposure to other external shocks. This may increase emerging markets' demand for insurance against capital flow volatility and balance of payments crises.

2. In the past, foreign currency-denominated external debt dominated the external liabilities of emerging markets. That has now shifted, with FDI and portfolio equity accounting for the majority of liabilities. Even external debt issued by these countries is increasingly denominated in their own currencies. This structure of liabilities is consistent with the objective of sharing risk across countries, with foreign investors bearing capital as well as currency risk on such investment. Emerging markets have thus accumulated enough good karma to cast off their "original sin." By contrast, portfolio debt and bank loans together constitute the major share of the external liabilities of advanced economies.

3. The asset positions of emerging market external balance sheets (not just for China) are becoming increasingly dominated by foreign exchange reserves, mostly held in government bonds issued by the four major reserve currency areas (U.S., Euro Area, Japan, U.K.). The recent global financial crisis has if anything accentuated the incentives for accumulating reserves for self-insurance purposes, thereby ensuring that the foreign demand for these advanced economy government bonds remains strong.

4. The level of public debt in the major reserve currency economies is high and rising, imposing an enormous burden on these economies and constraining their macroeconomic policy responses to shocks. A substantial fraction of the global increase in central government debt over the next five years is likely to be accounted for by advanced economies, especially the U.S. and Japan. As the safety of the sovereign bonds of advanced economies comes into question, the risk on emerging market balance sheets has now shifted mostly to the asset side. These countries may be forced to rethink the notion that advanced economy sovereign assets are "safe" assets, although they are certainly highly liquid.

\footnotetext{
${ }^{3}$ The term original sin was introduced by Eichengreen and Hausmann at the 1999 Jackson Hole Symposium. The term refers to the fact that, during the 1980s and 1990s, emerging markets' capital inflows were mostly in the form of short-term foreign currency-denominated external debt rather than more favorable forms of capital such as FDI or portfolio equity.
} 
5. Self-insurance through accumulation of ostensibly safe assets is becoming increasingly costly for emerging markets. Reserve accumulation involves intervention in foreign exchange markets and sterilization to mitigate the inflationary consequences thereof. The costs of conducting sterilized interventions are likely to rise in tandem with the rising differentials between the interest rates of emerging and advanced economies. Moreover, the high debt levels of advanced economies will crowd out private investment in those economies and could lower their productivity growth relative to emerging markets. This suggests that emerging market currencies are eventually going to appreciate against those of the advanced economies, which in turn implies a significant wealth transfer (in nominal domestic currency terms) in the future from the former group of countries to the latter.

6. Emerging market economies need a simple insurance mechanism that is characterized by ex-ante rather than ex-post conditionality in terms of a country's macroeconomic policies, does not involve the stigma associated with the IMF, and involves an unconditional payout at the time of a balance of payments crisis. To minimize moral hazard, the mechanism should offer insurance against liquidity risk rather than solvency risk. I offer a proposal that satisfies these criteria.

7. For emerging markets, the major risks from capital inflows are now less about balance of payments crises arising from dependence on foreign capital than about capital inflows accentuating domestic policy conundrums. For instance, foreign capital inflows add fuel to domestic credit expansions, a factor that made some emerging markets vulnerable to the aftershocks of the recent crisis. New risks from capital account openness are related to existing sources of domestic instability--rising inequality in wealth and in opportunities for diversification and sharing risk. Capital inflows and the resulting pressure for currency appreciations also have distributional implications as they exacerbate inflation, which disproportionately hurts the poor, and adversely affect the growth of industrial employment. For most emerging markets the right solution to these problems lies in establishing a richer set of financial markets to better absorb capital inflows and manage volatility, broadening access to the formal financial system (financial inclusion), and improving the quality of domestic institutions and governance. 


\section{Financial Globalization}

In the lead up to and right after the global financial crisis of 2008-09, much of the discussion about global capital flows was centered on global macroeconomic imbalances and the uphill flows of capital from emerging markets to advanced economies. To this day, there is a raging debate about whether or not these current account imbalances were an "equilibrium" phenomenon and how much they contributed to precipitating the financial crisis. Figure 1 shows that capital continues to flow uphill, although China and the U.S. now seem to be the key drivers of this phenomenon. ${ }^{4}$ While the ebbs and flows of current account balances have garnered much of the attention, in the background global financial integration has continued unabated.

In a process that started in the mid-1980s and picked up pace over the past decade, advanced economies and emerging markets have substantially increased their integration into global financial markets. This is evident from the rising gross positions of international assets and liabilities. Figure 2 shows that there has been a generalized increase in de facto financial openness, as measured by the ratio of the sum of gross stocks of external assets and liabilities to GDP. ${ }^{5}$ Among advanced economies, the median level of this ratio has more than doubled over the past decade. The increase is significant but smaller for emerging markets. By this criterion, advanced economies are much more integrated into global financial markets than the emerging market economies.

Table 1, which includes data for 2010, confirms that financial globalization increased sharply during the period 2000-07 and is on the rebound after the financial crisis. China and India were relatively closed in de facto terms in 2000 but have become much more

\footnotetext{
${ }^{4}$ For a more detailed documentation of uphill capital flows and their implications, see Prasad, Rajan and Subramanian (2007). Gourinchas and Jeanne (2009) note that conventional theoretical models predict that countries with higher productivity growth should attract more foreign capital, but data on the allocation of foreign capital across developing countries show the opposite.

${ }^{5}$ A standard dataset used in this literature is the External Wealth of Nations database constructed by Lane and Milesi-Ferretti (2007). Most of the major economies now report their international investment positions (IIP), although only for the last decade or so in many cases. I use official IIP data as the baseline source in this paper - this has an added advantage of helping me include 2010 data for many countries (the LMF dataset has been updated through 2009). I use LMF data for historical comparisons and for countries that do not provide IIP data.
} 
open since then. Other than Brazil and Russia, which experienced small dips, virtually every major economy — advanced or emerging — has a higher level of assets and liabilities relative to GDP in 2010 compared to 2007, indicating that the financial crisis did not reverse or stop rising global financial integration.

Rising gross external positions have important implications for growth, international risk sharing and financial stability. As gross stocks of external assets and liabilities grow in size, currency volatility will have a larger impact on fluctuations in external wealth and on current account balances. ${ }^{6}$ In particular, net factor income flows have already started playing an increasingly important role in driving current account fluctuations (rather than the trade balance, which used to dominate the current account for most countries). This has implications for evaluating appropriate/sustainable levels of current accounts.

Large gross positions imply far greater risks than those implied by net positions that may be small relative to the size of gross flows or stocks. Larger gross positions could mean greater volatility of capital flows due to external shocks as even modest portfolio rebalancing effects of international investors could lead to large fluctuations in net flows. Also, the level of net inflows may not be a good indicator of vulnerability if net flows are small relative to gross inflows and outflows. When an economy comes under pressure, gross inflows could stop and gross outflows could surge simultaneously, leading to a double blow in terms of net flows. ${ }^{7}$ Hence, countries may view rising gross positions as an incentive to accumulate more reserves to guard against externally-induced crises.

By the same token, large gross positions can provide better risk sharing, assuming that the currency, country and instrument composition of assets and liabilities is conducive to that. Given that country-specific risks cannot be insured within a country, cross-border flows or wealth redistributions are the relevant channel for international risk sharing. With large

\footnotetext{
${ }^{6}$ Obstfeld (2010) alluded to some of these issues in his remarks at last year's conference. Lane and Milesi-Ferretti (2008) analyze the factors that drive changes in countries' gross external positions.

${ }^{7}$ Forbes and Warnock (2011) analyze gross flows around crises and try to disentangle sudden stops or reversals of gross inflows (related to nonresident investors) from surges of gross outflows (by residents). They find that dynamics of gross inflows and outflows are driven by similar factors and that gross flows are more relevant than net flows for explaining currency crashes.
} 
gross positions, even small currency fluctuations can generate large implied wealth transfers across countries, although the implications for risk sharing are not always positive. $^{8}$

Typically, if a country faces a crisis such as a financial meltdown or pressures on its sovereign debt, its currency would depreciate, thereby automatically transferring some of the adjustment costs onto foreign holders of its liabilities. But this is true only if a country's liabilities are denominated in the domestic currency. Liabilities denominated in foreign currencies could exacerbate the impact of adverse shocks that lead to currency depreciation as the value of such liabilities would then rise in domestic currency terms. Domestic price dynamics combined with currency depreciation will then determine how the impact of adverse shocks is distributed among domestic agents and the foreign holders of a country's liabilities. The magnitudes of these effects also depend on the shares of liabilities and assets that are fixed-income instruments versus those that have an equity component; the latter involve more sharing of risk between domestic and foreign investors.

While rising gross positions clearly have a major impact, a closer examination of the structure of external assets and liabilities is warranted as that structure has implications for the potential benefits of financial integration in terms of both growth and risk sharing.

\section{Risk and the Structure of Country Balance Sheets}

I now turn to an examination of the international investment positions (IIP) of a set of major advanced and emerging market economies. The IIP is essentially a country's balance sheet vis-à-vis the rest of the world. It provides an indication of a country's gross external assets and liabilities as well as the composition of each side of the balance sheet.

\footnotetext{
${ }^{8}$ Currency fluctuations generate implicit wealth transfers due to currency valuation effects if external assets and liabilities are denominated in different currencies. Gourinchas, Rey and Truempler (2011) estimate that there was a substantial net "wealth transfer" of about \$2.2 trillion from the U.S. to the rest of the world over the period 2007Q4 to 2009Q1. This was at the height of the financial crisis and could in part reflect valuation effects from the strengthening of the dollar during that period as money flooded into the U.S. in search of a safe haven.
} 
Table 2 shows the latest IIP position for a key set of economies. Among the advanced economies, the U.K. and the U.S. have significant net liabilities while Germany and Japan have net asset positions. For all of these advanced economies, the category "other investment" - which mainly covers bank loans — is an important share of liabilities. When one adds in portfolio debt — which is mainly corporate as well as government debt-it is clear that debt accounts for the majority of external liabilities.

Among the emerging markets shown in this table, China has a large net asset position, Brazil has a significant net liability position and India has a small net liability position. Large net liability positions are no longer the norm for emerging markets. More importantly, there has been a dramatic shift in the external liability structure of emerging markets during the past decade. While in the past these economies' external liabilities were dominated by debt, now FDI and portfolio equity have become predominant. In 2010, these two components account for two-thirds of total external liabilities for Brazil and China, 51 percent for India and 56 percent for Russia (77 percent for South Africa). What is even more interesting is that, on the asset side, foreign exchange reserves account for a large share of total external assets-47 percent for Brazil, 69 percent for China, 68 percent for India and 37 percent for Russia (13 percent for South Africa).

Table 3 provides a more comprehensive picture of the structure of balance sheets for the two country groups and for some key economies at the beginning and end of the decade, as well as in the pre-crisis year--2007. The first two panels show the shares of FDI and portfolio equity liabilities, respectively, in total external liabilities. For emerging markets, the median share of FDI liabilities in total external liabilities increased by 9 percentage points over the decade. As measured by the group ratio (which essentially weights countries by the relative size of the liability stocks), the increase in the share of FDI is about 13 percentage points. Together the share of FDI and portfolio equity liabilities in total external liabilities has climbed to 61 percent. By contrast, for advanced economies, this ratio is much lower at 29 percent. 
On the asset side, the major shift on emerging market balances sheets lies in the increase in foreign exchange reserves as a share of total assets. The average share of foreign exchange reserves in total assets has risen from about 32 percent in 2000 to 53 percent in 2010. The median of country-specific ratios is lower, although there was still a 9 percentage point increase from 2000 to 2007 in the share of reserves in total external assets.

The changing structure of emerging market balance sheets can be seen more clearly in Table 4. Over the period 2000-2007, changes in FDI liabilities account for nearly half of the increase in overall liabilities. FDI and portfolio liabilities together account for about 70 percent of the increase in liabilities. On the asset side, reserve accumulation accounts for about half of the overall increase in external assets. As the last row of the table indicates, these results are not just driven by China. Indeed, a majority of the emerging markets experienced an increase in the share of foreign exchange reserves in total external assets over this period. Figure 3 shows that these changes reflect the continuation of a process that started in the mid-1980s and was only temporarily halted by the crisis.

These numbers reveal a striking shift in the composition of external portfolios of emerging markets. On the liabilities side, the shift towards FDI and portfolio equity is consistent with greater international risk sharing. ${ }^{9}$ As noted earlier, when the value of these investments falls either in domestic terms or due to a currency depreciation (or both), foreign investors bear part of the risk. One concern is that portfolio equity flows can be volatile and highly procyclical. In the face of a negative shock, portfolio investors might rapidly withdraw capital from a country thereby putting downward pressure on the currency. Nevertheless, the threat posed by outflows of portfolio equity capital is far less devastating than the rollover risk on short-term foreign currency debt that used to plague emerging markets.

The change in the structure of liabilities and the proliferation of flexible exchange rate regimes has substantially reduced emerging markets' vulnerability to balance of payments

\footnotetext{
${ }^{9}$ Kose, Prasad and Terrones (2009) show that for emerging markets FDI and portfolio equity liabilities improve international risk sharing outcomes. Debt liabilities have the opposite effect.
} 
and currency crises. This is not a uniformly true proposition, with emerging markets in Europe having become much more reliant on foreign bank loans before the crisis. But the large majority of emerging markets have indeed experienced these positive shifts.

Currency depreciations are far less of a risk for emerging markets now than they were in the debt-dominated era. First, the effects of such currency devaluations are likely to be small since emerging markets no longer have large stocks of foreign currency-denominated external debt, either sovereign or corporate. Thus, the devastating balance sheet effects that brought some Asian economies to their knees during the Asian financial crisis of 1997-98 are less of a concern today. Indeed, with many emerging markets now able to issue international debt denominated in their own currencies, even debt is no longer as fearsome as it once was. ${ }^{10}$

Second, currency depreciation generates a nominal wealth transfer in favor of the home country (in domestic currency terms) through valuation effects if a country's liabilities are denominated in domestic currency and assets are denominated in foreign currencies. This privilege was once limited to the large reserve currency economies but is becoming more widespread.

Competitive non-appreciations through intervention in foreign exchange markets now take on a more complex function as they involve not just the maintenance of price competitiveness in external trade but also serve to limit a country's wealth transfers to the rest of the world. ${ }^{11}$ Thus, among emerging markets, the fear of currency appreciation now has two underlying causes rather than just the implications for trade.

Even with this more benign structure of liabilities, emerging markets have not fully torn themselves away from the desire for insurance that would provide an infusion of liquidity

\footnotetext{
${ }^{10}$ Based on BIS data, Burger, Warnock and Warnock (2010) report that in 2008 local currency denominated debt accounted for 85 percent of the outstanding stock of international bonds issued by emerging markets. The shares for different regions are as follows: Emerging Europe--70 percent; Latin America--72 percent; Asia--95 percent. The International Finance Corporation reports that in 2008 local currency debt accounted for roughly 70 percent of emerging market debt. ${ }^{11}$ The ironic phrase about non-appreciation is attributed to Edwin Truman.
} 
at times of global crises. Figure 4 shows the rapid rate of reserve accumulation by emerging markets, which peaked in 2007, declined but remained positive in 2008-09, and then began to pick up again in 2010. Total foreign exchange reserves of emerging markets now amount to about $\$ 6.4$ trillion, with China accounting for half of this stock (Figure 5). The fact that several countries, including China and India, don't report the currency composition of their reserves has led to a rising share of reserves of unknown currency composition. For reserves whose currency composition is known, the U.S. dollar still remains dominant, accounting for about 60 percent of reserves. The euro's share has leveled off at around 30 percent. The Japanese yen and the pound sterling account for most of the remaining reserves whose currency composition is known.

The remarkable paradox in international finance is that the emerging markets' increasing desire for self-insurance has, if anything, increased global risks and transferred the major risks on those countries' balance sheets from the liability side to the asset side. The notion that the flow of official capital from emerging markets represents a search for "safe" assets seems rather tenuous if one examines the public debt trajectories of the advanced economies. I turn next to this issue.

\section{Global Debt and Reserve Dynamics}

The accumulation of reserves has been associated with a search by emerging markets for "safe assets" - typically government bonds of advanced economies. ${ }^{12}$ To examine the evolution of such assets around the world, I now examine trajectories of net government debt around the world. ${ }^{13}$

${ }^{12}$ Caballero, Farhi and Gourinchas (2008a, 2008b) argue that emerging markets' search for safe assets precipitated global macroeconomic imbalances. Mendoza, Quadrini and Rios-Rull (2010) make a related point that the greater financial depth of advanced economies attracts large inflows.

${ }^{13}$ I focus on central government securities as those are most relevant for reserve accumulation. Net debt is preferable for the purposes of my analysis as the remaining portion of gross debt is typically held domestically. The difference between gross and net public debt relates to intra-governmental holdings of debt. For instance, in the U.S., social security trust fund surpluses are held in government securities. These count towards gross but not net public debt. For the subject of this paper - the reliance of national governments on foreign financing of their debt - net debt is a more suitable concept. In any event, using gross rather than net debt strengthens the patterns in the data that I discuss below and accentuates concerns about public debt levels of advanced economies. For 
The global financial crisis triggered a sharp increase in public debt levels, both in absolute terms and relative to GDP. Data from the IMF's June 2011 Fiscal Monitor show that the level of aggregate net government debt in the world rose from \$22 trillion in 2007 to an expected $\$ 34$ trillion in 2011. IMF forecasts indicate the level will reach $\$ 48$ trillion in 2016. The ratio of world net debt to world GDP rose from 42 percent in 2007 to 57 percent in 2011, and is expected to hit 58 percent in 2016.

Since the onset of the crisis, the bulk of the increase in global public debt is accounted for by advanced economies. Relative to their GDP, debt levels in these economies are expected to continue rising in the next few years. By contrast, debt ratios will shrink for emerging markets. Indeed, advanced economies account for the bulk of the increase in global public debt since 2007, both in absolute terms and relative to GDP.

- Aggregate debt of advanced economies will increase from $\$ 18$ trillion in 2007 to $\$ 30$ trillion in 2011, and is expected to rise to $\$ 41$ trillion in 2016 (Figure 6). The corresponding numbers for emerging markets are $\$ 4$ trillion, $\$ 5$ trillion and $\$ 7$ trillion, respectively. ${ }^{14}$

- The ratio of aggregate debt to aggregate GDP for advanced economies will rise from 46 percent in 2007 to 70 percent in 2011 and further to 80 percent in 2016. The corresponding ratios for emerging markets are 28 percent, 26 percent and 21 percent, respectively.

There is a stark contrast between the two groups of countries in their relative contributions to growth in world debt versus growth in world GDP. Emerging markets contribute far more to growth in global GDP than to the growth in global public debt. Some illustrative statistics follow:

more detailed data, including estimates of the burden of central government debt (debt per capita or per working-age person), see Prasad and Ding (2011) and www.ft.com/debtburden.

${ }^{14}$ The reported debt levels of emerging markets should be interpreted with caution. In China, for instance, financial liabilities of provincial governments and contingent liabilities such as nonperforming assets held by the state-owned banking system imply a much higher value of government debt obligations than indicated by official statistics. Of course, as the recent crisis has shown, advanced economy governments arguably have similar implicit contingent liabilities if their big banks were to run aground or their public pension systems were to run out of money. 
- In 2007, emerging markets accounted for 25 percent of world GDP and 17 percent of world debt (Figures 7-8). By 2016, they are expected to produce 38 percent of world output and account for just 14 percent of world debt.

- In 2011 (based on IMF estimates at market exchange rates), the four major reserve currency areas together account for 58 percent of global GDP and 81 percent of global debt.

- Emerging markets account for 9 percent of the increase in global debt levels from 2007 to 2011 and are expected to account for 13 percent of the increase from 2011 to 2016 (Figure 9). By contrast, their contributions to increases in global GDP over these two periods are 66 percent and 56 percent, respectively.

- The two biggest advanced economies are making a far greater contribution to the rise in global debt than to the rise in global GDP. The U.S. contributes 37 percent of the increase in global debt from 2007 to 2011 and 40 percent from 2011 to 2016. Its contributions to the increases in global GDP over those two periods are 8 percent and 18 percent, respectively. Japan accounts for 20 percent of the increase in debt from 2007 to 2011 and 34 percent from 2011 to 2016 while its contributions to the increase in global GDP are 4 percent and 8 percent, respectively.

High and rising debt levels among advanced economies pose serious risks to global macroeconomic stability. Of course, the implications of rising debt levels and their sustainability depend to a large extent on whether these debts are financed from domestic savings or by foreign investors. In the case of the U.S., foreign investors-both official and private- - hold about half of the outstanding stock of net central government debt (Figure 10). This ratio is lower for the U.K.- about one-third of its net debt is held by foreign investors - and even lower-less than 10 percent - for Japan, which has a very high domestic savings rate. I have not been able to find comprehensive figures for the euro area. IMF data suggest that the ratio is between 40-50 percent for Germany, Italy and Spain and much higher for some of the smaller economies such as Greece and Ireland, although these figures include within-euro area holdings and do not provide a clear picture of how much euro area sovereign debt is held by investors from outside the euro area. 
Figure 11 provides further detail on the extent to which foreign investors finance U.S. debt accumulation. The figure shows the increase in the net stock of outstanding debt and the increase in the share of net debt held by foreign investors. Foreign investors have played an important role in the financing of net U.S. debt. During 2008-10, when net debt accumulation soared to $\$ 1.3$ trillion per year, foreign investors accumulated $\$ 695$ billion per year, accounting for just over half of total U.S. net debt issuance.

These figures paint a sobering picture of worsening public debt dynamics and a sharply rising public debt burden in advanced economies, along with a high level of dependence on foreign investors in search of a safe haven, especially in the case of the U.S. The major reserve currency economies - especially the U.S. and Japan-face daunting trajectories of public debt and weak growth prospects. These economies have had the benefit of being able to issue sovereign debt in their own currencies, allowing them to essentially transfer currency risk to the foreign purchasers of their sovereign debt.

Advanced economies have not been subject to original sin but their accumulated sins will eventually catch up with them. Indeed, with low levels of population growth, rapidly aging populations and rising costs of health care and other entitlement programs, advanced economies could be in far worse shape beyond the medium-term horizon discussed in this section if they do not bring their public finances under control. ${ }^{15}$

As demonstrated by recent events in the euro zone, bond investors - both domestic and foreign — can quickly turn against a vulnerable country with high debt levels, leaving the country little breathing room on fiscal tightening and eventually precipitating a crisis. The U.S. is large, special and central to global finance but the tolerance of bond investors may have its limits.

In advanced economies, rising public debt levels imply significant crowding-out effects that will affect productivity growth and could generate a persistent productivity growth gap

\footnotetext{
${ }^{15}$ Cecchetti, Mohanty and Zampolli (2010) present sobering projections of advanced economies' long-term debt levels under current policies in those countries.
} 
relative to emerging markets. Balance sheets of households and the financial sector in advanced economies were severely damaged by the financial crisis and are only now beginning to recover, putting a further crimp on these economies' growth prospects. All of this implies that emerging markets' currencies will in the long run tend to appreciate relative to those of the major advanced economies, implying a large wealth transfer from poorer to richer economies.

If one looks at the overall level of foreign exchange reserves and the fact that nearly all of these reserves are held in U.S. dollars, euros and yen, the implications in terms of a capital loss in domestic currency terms for emerging markets are quite significant. For instance, for China, a 10 percent decline in nominal exchange rates against each of the major reserve currencies would imply a capital loss of about 300 billion dollars just from currency valuation effects. ${ }^{16}$ These issues raise serious questions about what it means for emerging markets to hold government bonds of advanced economies as safe assets.

With these unfavorable debt dynamics, why is the U.S. still in the position of being liquidity provider of last resort? The same question can be asked of the other major reserve currency economies. The answer must lie in the quality of public institutions as well as financial market depth, which means that at least investments in those countries' bonds are liquid and easily tradable. The rush into U.S. treasury bonds in the presence of global financial turmoil is then more a flight to liquidity and depth than a flight to safety.

How can emerging market countries protect themselves against external crises precipitated by global shocks? How can they do this without incurring huge insurance costs? Are there any alternatives that emerging markets can count on in the absence of really safe and liquid assets? I now sketch a proposal that attempts to tackle these issues.

\footnotetext{
${ }^{16}$ A counter-argument is that the currency value is of little consequence as the dollar holdings represent claims on U.S. goods and services that are denominated in dollars. This argument assumes that the high U.S. debt levels will not have major inflationary consequences in the U.S. Another issue is that, in the process of sterilizing inflows, the People's Bank of China has issued central bank bonds that are effectively liabilities denominated in renminbi and match a significant proportion of the dollar assets. Even if the capital loss on the dollar-denominated assets nets out within the government as the PBOC bonds are held by state-owned banks, the real cost is the massive financial repression needed to maintain the tightly-managed exchange rate regime.
} 


\section{Global Liquidity Insurance}

To being with, consider why countries accumulate reserves. Some countries like China have built up reserves in the process of keeping their currency undervalued, thereby increasing their export competitiveness but at the cost of less balanced growth. Another objective is to accumulate reserves as insurance against volatile capital flows and to smooth associated fluctuations in aggregate consumption. Reserves can also be used to fend off attacks on the domestic currency, although this is less of a concern for countries with flexible exchange rates. It is difficult to evaluate the extent of reserve accumulation that is attributable to precautionary motives as opposed to mercantilist policies. If an alternative to self-insurance were available, one would have a more straightforward answer to this question.

How much insurance is enough? Conventional criteria suggest a level sufficient to cover 6 months of imports or the stock of short-term external debt maturing over the next year (the Greenspan-Guidotti rule). By these criteria, most major emerging markets had accumulated more than sufficient reserves by the early 2000s. Other criteria, related to measures of financial stability and financial openness, do a better job of explaining the incentives behind the sharp run-up in reserves during the past decade. But even with this set of augmented criteria it is difficult to fully rationalize the continued increase in reserves after the mid-2000s, especially among Asian economies. ${ }^{17}$

In any event, all such notions of reserve adequacy took a beating during the crisis. India lost about $\$ 66$ billion of its stock of $\$ 305$ billion of foreign exchange reserves in a matter of 6 months. Russia's reserves fell by a third over a 7-month period starting from July 2008. Table 5 shows that, in a selected group of 13 emerging markets that experienced

\footnotetext{
${ }^{17}$ A speech by Jose De Gregorio (2011), Chile's central bank governor, explicitly references reserve accumulation for precautionary purposes. Obstfeld, Shambaugh and Taylor (2010) estimate a model of reserve stocks that includes M2, financial openness, ability to access foreign currency through debt markets, and exchange rate policy. These variables do better at explaining emerging markets' reserve accumulation during the 2000 s than traditional models that only include imports and external short-term debt. For other analyses of accumulation motives and criteria for reserve adequacy, see Aizenman and Lee (2007), Jeanne (2007) and Dominguez, Hashimoto and Ito
} (2011). 
significant reserve losses, the median reserve loss was 27 percent of peak reserves over a seven-month period. Some emerging markets did not lose much of their stock of reserves; China even continued to accumulate reserves through the crisis period. Nevertheless, with rising financial integration and ever larger positions of gross flows and stocks, in the aftermath of the crisis emerging markets face stronger incentives to obtain higher levels of insurance through the accumulation of massive stocks of reserves. Indeed, virtually all emerging markets have been rebuilding or continuing to increase their reserve stocks after 2009. The last column of Table 5 shows that, by April 2011, most of the countries that experienced major reserve losses during the crisis had rebuilt their reserve positions and were approaching or had already exceeded their pre-crisis levels of reserves.

Self-insurance tends to be costly for emerging markets that have to tie up resources in advanced economy government bonds rather than using them to meet their own physical capital investment needs. Another cost involves the higher yields paid on domestic government bonds used to sterilize the liquidity effects of foreign inflows relative to the low yields earned on reserves held in advanced economy bonds. Some economies limit their sterilization costs through financial repression. In China, bank deposit rates are capped, allowing state-owned banks to buy central bank bonds for relatively low yields while still making a profit. Financial repression, in addition to impeding the efficient operation of financial markets, has direct costs to households. ${ }^{18}$ Such insurance may also prove expensive in the long run in terms of an eventual capital loss from the anticipated depreciation of advanced economy currencies relative to those of emerging markets or if advanced economy governments drive down the real value of their bonds through inflation.

Moreover, there is a collective action problem associated with reserve accumulation by emerging markets as it provides cheap financing for the fiscal profligacy of advanced economies while increasing the risks of future crises. During the financial crisis, the concern prevailed that if a number of emerging markets simultaneously tried to liquidate their holdings of U.S. government securities, financial markets could be further

\footnotetext{
${ }^{18}$ See Prasad (2009a) for a discussion of this issue in the context of China. Lardy (2010) estimates the cost to households of financial repression in China - as captured by the low or negative real interest rates paid on households' bank deposits - at about 4 percent of GDP per annum.
} 
destabilized. Thus, in many ways, massive reserve accumulation makes those reserves less valuable at a time of global crisis and in fact reduces the value of insurance as it heightens global risks. Regional insurance pools can alleviate some of these problems but are likely to prove inadequate if a number of countries in a region are subject to the same shock.

How then can we obviate the motives for self-insurance by emerging markets, along with the costs and risks that the associated policies imply?

\section{A Proposal for Global Insurance}

My proposal falls out in a straightforward manner from the previous discussion. The obvious answer is an insurance pool for the world's major economies - mainly but not necessarily just for the emerging markets. Each country would pay a modest entry fee between $\$ 1$ and 10 billion, depending on its size as measured by GDP, to provide an initial capital base. It would then pay an annual premium for buying insurance that it could call upon in the event of a crisis.

The premium would depend on the level of insurance desired and could on average be about 5 percent of the face value of the insurance policy ( $\$ 5$ billion in annual premiums for $\$ 100$ billion of insurance). This premium level would be of roughly the same order of magnitude as the quasi-fiscal cost of reserve accumulation through sterilized intervention and the implied cost of a 2-3 percent annual depreciation of the reserve currencies' values against emerging market currencies over the long term, based on productivity growth differentials.

The level of the premium in a particular year would depend not only on the level of insurance desired but also the quality of a country's policies. There would be higher premiums for a country that chose to run large budget deficits or that accumulated large amounts of debt, thereby increasing its vulnerability to crises. The principle is analogous to car insurance, where owners of more expensive cars and riskier drivers (based on verifiable characteristics like age and gender) face higher premiums. There would be discounts from the base level for countries that have demonstrated policy discipline. 
Premiums would have to be based on simple and transparent rules. For instance, a current account deficit larger than 2 percent of a country's GDP triggers a higher premium. Other criteria that affect premia could be based on variables such as fiscal deficits, public debt and external debt (all relative to GDP). To keep things simple, there would be no countryspecific adjustments--such as adjusting the budget deficit for business cycle conditions-that would be contentious and also difficult to deal with in real time.

The premiums would increase in a nonlinear fashion with the persistence and levels of policies that contributed to an economy's vulnerability. A country running large budget deficits or continuing to accumulate large stocks of external debt in successive years would pay rising premiums in each of those years. In this way, the country's contributions to rising global risks would be accounted for. Likewise there would be a nonlinear premium schedule for countries requiring larger levels of insurance relative to their economic size. As the premiums and the size of the insurance pool increased, the premiums could gradually be scaled down for all countries.

This is a transparent rules-based mechanism to strengthen the power of moral suasion to get a country to at least partially internalize the effects of its own policies on global risks. There is no stigma or signaling effect associated with the premium levels as they are based on country variables that are all public knowledge. ${ }^{19}$

The premiums could be tweaked with a novel feature - charge higher premiums from countries with policies that might serve them well individually but could drive up global risks. A country may well decide that accumulating a large stock of reserves by preventing currency appreciation is in its own interest. There is not much the world could do about this other than retaliating by blocking trade from that country, which could start a trade war that hurts everyone.

So why not just charge that country a higher premium based on the size of its stock of

\footnotetext{
${ }^{19}$ Some commentators have suggested that these premiums could be linked to market-based measures of country risk as captured by debt or CDS spreads. However, policymakers will be reluctant to participate in an insurance scheme where premiums are subject to shifts in market sentiments that may or may not be based on economic fundamentals.
} 
reserves relative to GDP. Extending the automobile insurance analogy, this would be like charging a higher premium of drivers who insist on driving at a speed that is only half the posted speed limit, thereby raising the risks for other drivers who have to get around them. The premiums would not be large enough to deter a country that had legitimate needs for some self-insurance but it would be an effective tool of moral suasion against bad policies (from a global perspective) if a country had to pay higher premiums when its economy was doing well.

\section{Operation of the Insurance System}

The premiums would be invested in a portfolio consisting of government bonds of the U.S., Euro area and Japan. In return, the Federal Reserve, European Central Bank (ECB) and Bank of Japan would be obliged to backstop the pool's lines of credit in the event of a global crisis. This would simply institutionalize ex-ante swap arrangements of the sort that the G-3 central banks opened up ex-post during the crisis to provide liquidity to other central banks.

The insurance payout would be in the form of a credit line open for a year rather than an outright grant. The interest rate would be non-punitive and based on the yields on shortterm government securities in the countries backing up the insurance pool.

The country drawing on this insurance would be required to pay back the borrowed amount within the one-year period in the same hard currency that it gets for the loan. So if a country's currency depreciated in the ensuing year, it would have a higher debt burden in domestic currency terms, which to some extent would be a disincentive for the country to persist with bad policies under the protection provided by the credit line. The country would not be able to buy additional insurance until there was a full repayment of the initial draw from the insurance pool. Premiums would be raised substantially if a country wished to renew its insurance in the next period after drawing on the credit line without any improvements in its policies.

Thus, the insurance would only be suitable for liquidity crises. For an economy beset by a solvency crisis, the insurance payout would effectively buy a limited amount of breathing 
space. Indeed, one could think of reserve accumulation as being relevant for solvency risk and this insurance mechanism as being relevant for liquidity risk. Once the credit line lapses and if the country turns out to have a solvency rather than liquidity problem (which may be difficult to determine ex-ante), then the premiums would rise to punitive levels. In that case, the country goes to the IMF for traditional borrowing with ex-post conditionality.

This mechanism is different from traditional insurance where the idea is to pool risks. In this case, the main risk may be global rather than country-specific. This also makes it hard to price the premiums in an actuarially "fair" way as the major risks are by definition correlated across countries shock if the underlying shock is global.

\section{Why Can't the IMF Provide Such Insurance?}

In principle, the IMF is the right institution to manage such an insurance mechanism. It has become recognized as an independent arbiter of good policies. Besides, there is logic to this arrangement - if a credit rating agency had to stand behind its ratings by being on the hook for bailing out companies whose finances it rated as being rock solid, that would certainly make a difference to the quality of ratings.

However, there are three problems. First, the (much-needed) austerity policies that the IMF foists upon countries has made any involvement with the IMF toxic for politicians in emerging markets, especially in Asia. Hence the urge for countries to self-insure by accumulating reserves, even if that is costly. Second, IMF programs to pre-qualify countries for emergency assistance are a source of stigma. Application for pre-qualification could itself be seen as a sign of weakness. Indeed, the fact that only three countriesMexico, Colombia and Poland-have signed up for the IMF's Flexible Credit Line (FCL), which was intended as a pre-qualification mechanism, points to these problems. ${ }^{20}$ Third,

\footnotetext{
${ }^{20}$ There is some evidence that signing up for the FCL reduced spreads on these countries' debt, but that evidence has apparently not been sufficient to overcome the stigma effect as there have been no additional takers for the FCL. The poor cousin of the FCL is the Precautionary Credit Line (PCL), designed to "meet the needs of countries that, despite having sound policies and fundamentals, have some remaining vulnerabilities that preclude them from using the FCL." Shockingly, only one country-Macedonia — has so far volunteered to have its policies rated as being good but not quite good enough for the PCL.
} 
IMF resources are simply not enough — even a trillion dollars is not what it used to be, especially in the context of a global crisis. Moreover, the value of an IMF loan used to be that the good housekeeping seal of approval of a country's policy commitments accompanying that loan would induce private capital to flow in. As the events during the financial crisis have shown, that multiplier effect of IMF lending cannot be counted on during a global crisis.

A fundamental problem is that the IMF has two key roles in the international monetary system: the surveillance function-monitoring of countries' economic policies and performance - and crisis lending. These two roles are incompatible if the objective is to provide global insurance through the IMF and reduce incentives for the systemically important emerging market economies to self-insure by building up huge war chests of reserves. The IMF cannot credibly commit to maintaining an open credit line and not imposing ex-post conditionality with its loans if a country that qualifies for the FCL starts running bad policies. Besides, what the IMF giveth the IMF can take away as the rules of the game can obviously be changed quickly in the midst of a crisis.

My proposal would free up the IMF to do what it does best-conducting surveillance and fixing the policies of countries that have brought upon themselves solvency problems in terms of domestic or external debt.

\section{Other Questions}

Why can't the Federal Reserve or the ECB directly provide credit lines to countries? The reason is that the determination of these credit lines then becomes a political matter. If there is uncertainty about which countries will receive the Federal Reserve's benedictionduring the recent crisis, countries like Mexico and South Korea did while others like Peru did not—emerging markets cannot count on being protected by the major central banks.

Can the IMF's Special Drawing Rights (SDRs) provide such insurance? SDRs have limited value as an international reserve currency since they lack the fiscal backing of a 
sovereign government. ${ }^{21}$ Moreover, emergency SDR allocations distributed on the basis of existing quotas would hardly be sufficient for the major emerging markets. A reallocation of SDRs to deliver them where they are most needed again becomes a political decision. Most countries would want to avoid placing themselves at the mercy of shifting political winds at the IMF.

The crux of my proposal is that it depoliticizes access to liquidity, either from the major advanced economy central banks or through SDR allocations, in the event of a major global shock.

Is it politically feasible for a national government to pay premiums for such insurance? Given that this option would be cheaper than the quasi-fiscal costs of sterilizing reserves that are built up for insurance purposes, would not involve currency risk, and involves a relatively modest premium, it should not be difficult for a government to make a strong case to its constituents for participation in such a scheme.

Low-income countries might not be able to afford such insurance. But they need developmental assistance, not protection from currency crises. So this would initially be an insurance pool meant primarily for systemically important countries or even a broader range of middle-income economies, although others would be welcome to join.

\section{Participation}

Would the large economies, especially the major emerging markets, want to sign on to this program? Broad participation by the G-20 economies would be important for obviating the stigma effect. Unlike in health insurance where broadening the pool by mandating universal participation reduces premiums and adverse selection, the broad mandate here would mainly be to deal with the stigma effect.

The solution is simple-make participation in this pool a condition for continued

\footnotetext{
${ }^{21}$ Obstfeld (2011) makes this point and discusses other impediments to the SDR becoming a global reserve currency.
} 
membership in a body such as the Financial Stability Board (FSB), where all countries would like to have a seat as it will have an important role in developing principles for international financial regulation (participation in the insurance pool would, however, not be a guarantee of membership in the FSB). This would remove the stigma effect and also have the virtue of tying together financial and macroeconomic policies, as their interaction is clearly crucial for global economic outcomes. Indeed, the FSB or Bank for International Settlements could easily administer this program. No country would be forced to buy insurance, of course, but would have to pay the basic membership fee to be part of the pool.

\section{Broader Benefits}

If the insurance-related motive for reserve accumulation were attenuated by this explicit insurance scheme, it could help discipline advanced economies' fiscal policies by raising their borrowing costs. ${ }^{22}$ This would also tamp down private capital flows to emerging markets, an added benefit for countries in that group concerned that cheap money in the U.S. and other advanced economies is flowing disproportionately to them and causing complications in their domestic macroeconomic management.

The existence of such an insurance scheme would also help separate out the motivesmercantilist versus precautionary - behind foreign exchange intervention and related reserve accumulation. The costs of reserve accumulation are seen by some emerging market policymakers as being balanced by the joint benefits of insurance and maintaining trade competitiveness. By providing an alternative (and cheaper) option for insurance, the mechanism I propose would force emerging market economies to more directly consider the costs of protecting trade competitiveness through intervention in currency markets.

Global financial stability is in everyone's interest but it involves solving a collective action problem. This scheme would help get the incentives right. First, it reduces the incentives for emerging market economies to self-insure; in the event of a liquidity crisis, they would

\footnotetext{
${ }^{22}$ Even though the insurance premiums would be invested in advanced economy bonds, the amounts would be far less than the amounts that emerging markets may otherwise accumulate for self-insurance through reserve accumulation.
} 
have access to a large insurance pool with no conditions attached. This would allow them to conduct better macroeconomic policies rather than focus on accumulating reserves. Second, it mitigates the risk of spiraling global macroeconomic imbalances and the attendant risks of crises and their spillover effects. Third, it creates a transparent mechanism by which the global costs of a country's policies would be internalized to some extent or, at a minimum, made more visible.

\section{New Risks from Capital Inflows}

The next decade will be one where advanced economies are more vulnerable to external crises while emerging market economies are more exposed to domestic fragilities. Traditionally, emerging markets were exposed to risks through their dependence on capital inflows and the structure of their external liabilities. Few of the significant emerging markets are now heavily dependent on foreign finance in terms of net inflows. Even those economies like Brazil and India that are running current account deficits have large stocks of foreign exchange reserves. ${ }^{23}$ And the scourge of short-term foreign currency denominated debt has diminished substantially. Flexible exchange rate regimes adopted by many emerging markets have also made currency crashes, which often followed a long period of forced disequilibrium in currency markets, less of a concern.

Nevertheless, the high levels of financial integration do imply that emerging markets will be subject to greater policy spillovers and transmission of shocks from the advanced economies. For instance, pure contagion effects due to portfolio rebalancing by advanced economy investors could be larger as gross positions increase in size. But these risks are still likely to be modest relative to domestic ones.

\section{Capital Flows and Domestic Risks}

For emerging market economies, the risks of financial openness will increasingly be intermediated through domestic factors. For instance, narrow financial markets can result in asset market booms when capital flows into a country. In the absence of regulation that

\footnotetext{
${ }^{23}$ There are of course exceptions. One is Turkey, which is in a vulnerable position as it has a large current account deficit and relies mainly on volatile portfolio equity inflows to finance that deficit.
} 
is effective and well implemented, inflows can inflate credit booms that eventually end badly. ${ }^{24}$ One solution is to foster a broader set of financial markets, including corporate bond markets and other securities markets for which there is already an intrinsic demand. This would help absorb inflows and direct them to more productive rather than speculative sectors of the economy.

Financial market development that fails to keep pace with increasing outward orientation of domestic firms also creates risks for emerging markets. Firms have an incentive to take on foreign-currency denominated debt as a way of hedging against (or even betting on) currency appreciation. Broader derivatives markets can help deal with this source of risk.

Capital flows have distributional consequences, a matter of particular concern to emerging market economies that are nervous about social stability as many of them have threadbare social safety nets. ${ }^{25}$ More open economies tend to be prone to higher inequality for a number of reasons. First, during the early stages of an economy's opening up, capital account openness tends to favor the rich and the elites. In the early stages, when there are still restrictions on foreign capital, politically well-connected firms obtain preferential access to foreign financing; large politically connected firms can become even larger relative to smaller domestic firms that are reliant on inefficient domestic financial institutions. This phenomenon of crony capitalism played a role in precipitating the Asian financial crisis. ${ }^{26}$ Larger firms in the manufacturing sector typically tend to be more capital intensive and generate less employment, further skewing the benefits from financial openness.

Second, foreign finance that pours into equity markets and raises valuations tends to have greater benefits for households that have more financial wealth in the form of equity

\footnotetext{
${ }^{24}$ Kose and Prasad (2010), Frankel and Saravelos (2011) and Gourinchas and Obstfeld (2011) identify rapid expansion of domestic credit in the run-up to the recent crisis as a factor that led to worse outcomes for some emerging markets, particularly those in Emerging Europe.

${ }^{25} \mathrm{Ye}(2011)$ reports preliminary evidence that greater financial openness is associated with greater wage inequality among emerging market economies. Rajan (2010) discusses how, even in the U.S., inequality and a feeble safety net led to distorted government policies that ultimately led to an unraveling of the financial system.

${ }^{26}$ See, for instance, Krueger and Yoo (2002).
} 
investments. Third, capital account openness can create inequities in terms of diversification and risk sharing. Richer households are able to share risk through their international investments. Even in countries with open capital accounts, this is a problem for poorer households that simply do not have investment vehicles to invest abroad. Fourth, since poorer households have less access to foreign investment opportunities, they disproportionately bear the costs of domestic financial repression. For instance, in China, capital controls on outflows have been eased, allowing households to take out $\$ 50,000$ each per year, a large sum by most standards. However, relatively poor households do not have access to vehicles like mutual funds to easily invest abroad. So the available choices are either the highly volatile Chinese stock market or safe bank deposits that pay negative real interest rates.

The combination of weak policies and weak institutions generally has more adverse consequences in emerging markets compared to advanced economies. For instance, financial repression in advanced economies is less of a concern from the perspective of generating inequitable outcomes as there are other investment opportunities available to retail investors, making them less reliant on domestic banks.

Ultimately, the main collateral benefit of financial opening might be that it forces national governments to put in place better policies. There is little evidence that financial globalization has improved the quality of fiscal and monetary policies, but perhaps the real issue is about an alternative set of policies that creates broader financial access to the formal financial system, catalyzes better public and corporate governance, and provides a strong incentive for financial market development. ${ }^{27}$

\section{Policy Complications}

The longer-term perspectives discussed above are of little comfort to emerging market policymakers facing immediate pressures from capital inflows. Capital controls have been

\footnotetext{
${ }^{27}$ For more discussion of the potential collateral benefits of financial globalization and why they may be more important than the direct financing effects of foreign capital, see Kose, Prasad, Rogoff and Wei (2009).
} 
touted as a legitimate tool to deal with surges of inflows. Such inflows can certainly leave long-lasting scars on a country's tradable goods sector and export market shares if they result in persistent currency appreciations. There are many problems with capital controls, however. As trade expands, financial markets develop and become more sophisticated, and corporations and financial institutions increase their cross-border operations, the capital account becomes porous and capital controls are more easily circumvented, especially if the incentives such as cross-border interest differentials are strong enough. This makes capital controls largely ineffective in terms of controlling the overall volume of flows. ${ }^{28}$

What about selective capital controls - is it possible to use the hierarchy of capital flows to develop guidelines under which countries may intervene in foreign exchange markets or use targeted capital controls with the blessings of the international community? The problem with this latter approach is that money tends to be quite fungible. Indeed, in countries with relatively well-developed financial markets, such fungibility is an even bigger issue and it has proven difficult to keep money from coming in (or leaving) through multiple channels. Moreover, most major emerging markets now have relatively open capital accounts, especially in de facto terms, and trying to turn the clock back is unlikely to be effective and would just create policy uncertainty.

Determining when capital controls are legitimate requires fine judgments about the temporary versus persistent nature of flows, which is difficult in real time. The same is true of determining whether current account balances are being driven by transitory or permanent shocks, which makes it difficult to arrive at judgments about their appropriate level. Determining the appropriate level of current account balances will become even more complicated as current accounts become increasingly driven by valuation effects and earnings on countries' external portfolios.

The IMF has proposed the creation of "rules of the road" to protect countries that have the right policies but get caught up in spillovers of global turmoil or in policy spillovers from

\footnotetext{
${ }^{28}$ See, for instance, Magud, Reinhart and Rogoff (2010). Kose, Prasad, Rogoff and Wei (2009) discuss how de facto financial integration is proceeding faster than de jure financial opening for many middle-income economies.
} 
large economies. To make progress on this requires clear benchmarks against which to evaluate current account balances and capital flows. Economic theory in its current form does not provide good benchmarks for evaluating the direction and patterns of capital flows, especially given various aspects of market incompleteness, information asymmetries, institutional weaknesses and other frictions. This will make it difficult to construct useful rules of the road that have general applicability. This is an area where intensive academic research is sorely needed to generate better analytical frameworks, although it is still not clear if such rules are desirable or enforceable.

Rather than focus on evaluating the appropriateness and sustainability of current account balances and exchange rates, a more productive analytical approach might be to ask what market failures are leading to a pattern of capital flows that is not efficient and increases global risks. Unconstrained leverage is a problem that can be handled through regulatory tools. Other than that, many problems in terms of policy spillovers can be traced to weak macroeconomic frameworks among both the suppliers and recipients of capital. Dealing with the effects of one set of distortions by adding more distortions in the form of capital controls and other ad hoc measures may ultimately prove counter-productive by exacerbating policy instability.

A better approach is to improve a range of other policies, from financial development and banking regulation to fiscal and monetary policies, so that capital flows in a more stable and efficient manner. For instance, broader and better-regulated financial markets can help emerging markets to absorb inflows and effectively intermediate them into productive rather than speculative activities.

It is also in the self-interest of emerging markets as a group to foster financial market development. This will allow them to invest more amongst themselves rather than finance fiscal profligacy in advanced economies. Advanced economies' deeper and broader financial markets have made it easier for them to finance their deficits and allowed a number of them to avoid major reforms notwithstanding crises that they experienced. In 
the case of emerging markets, by contrast, financing constraints made significant policy reforms imperative when these economies were hit by crises.

One paradox is that in the short run emerging markets with better financial markets and good growth prospects may end up having to deal with a larger quantum of flows than those with underdeveloped financial markets that intrinsically limit foreign investment. There are few easy answers to these transitional risks.

\section{Concluding Remarks}

In this paper, I have documented dramatic shifts in the composition of emerging markets' balance sheets. Their liabilities have come to be dominated by FDI and portfolio equity flows, while their assets are increasingly in the form of foreign exchange reserves. In tandem with the uphill flows of capital characterized in other studies, this implies a sharp role reversal between emerging markets and advanced economies. Emerging markets have not only become net exporters of capital to the advanced economies but have also substantially reduced the risk emanating from the structure of their external liabilities even as advanced economies' external liabilities continue to be dominated by debt.

At one level, financial globalization seems to proceeding along the right track. Emerging markets are getting more capital in forms that promote international risk sharing and make them less vulnerable to sudden shifts in sentiment. Overall, their dependence on foreign capital is limited. As a group they have become net exporters of capital and even those countries like Brazil and India that have current account deficits have large stocks of reserves. Many of these countries have also adopted better monetary policy frameworks with flexible exchange rates, reducing the risk of currency crashes.

This picture is clouded by the fact that advanced economies have boxed themselves in with undisciplined fiscal policies that could erode their productivity and growth. Moreover, the external liabilities of these economies continue to be dominated by debt. Even though a large share of their external liabilities is denominated in their own currencies, leverage and weak regulation have proven to be a toxic combination in many advanced economies. In 
tandem with rising domestic and external sovereign debt, this makes them vulnerable to adverse shocks. It is high time for advanced economies to take the tonic of macroeconomic and structural reforms that they have for so long dispensed to the emerging markets. 


\section{Appendix A: Country List}

Advanced Economies (29): Australia, Austria, Belgium, Canada, Czech Republic, Denmark, Estonia, Finland, France, Germany, Greece, Hong Kong, Iceland, Ireland, Israel, Italy, Japan, Korea, Netherlands, New Zealand, Portugal, Singapore, Slovak Republic, Slovenia, Spain, Sweden, Switzerland, United Kingdom, United States.

Emerging Markets (29): Argentina, Brazil, Bulgaria, Chile, China, Colombia, Hungary, India, Indonesia, Jordan, Kazakhstan, Kenya, Latvia, Lithuania, Malaysia, Mexico, Morocco, Nigeria, Pakistan, Peru, Philippines, Poland, Romania, Russia, Saudi Arabia, South Africa, Thailand, Turkey, Ukraine. 


\section{References}

Aizenman, Joshua, and Jaewoo Lee, 2007, "International Reserves: Precautionary versus Mercantilist Views: Theory and Evidence," Open Economies Review, Vol. 18, pp. 191-214.

Aizenman, Joshua, Menzie D. Chinn, and Hiro Ito, 2010, "The Emerging Global Financial Architecture: Tracing and Evaluating the New Patterns of the Trilemma's Configurations," Journal of International Money and Finance, Vol. 29, No. 4, pp. 615-641.

Burger, John D., Francis E. Warnock, and Veronica Cacdac Warnock, 2010, "Investing in Local Currency Bond Markets," NBER Working Paper No. 16249.

Caballero, Ricardo J., Emmanuel Farhi and Pierre-Olivier Gourinchas, 2008a, "Financial Crash, Commodity Prices, and Global Imbalances," Brookings Papers on Economic Activity, Fall, pp. 1-55.

Caballero, Ricardo J., Emmanuel Farhi and Pierre-Olivier Gourinchas, 2008b, "An Equilibrium Model of 'Global Imbalances' and Low Interest Rates," American Economic Review, Vol. 98:1, pp. 358-393.

Cecchetti, Stephen G., M.S. Mohanty, and Fabrizio Zampolli, 2010, "The Future of Public Debt: Prospects and Implications,” BIS Working Paper No. 300.

De Gregorio, Jose, 2011, "Chile: Policy Responses to the Global Crisis," presentation delivered at the Conference Monetary Policy and Central Banking in the Post Crisis Environment, Central Bank of Chile and Global Interdependence Center, January 17, Santiago, Chile.

De Gregorio, Jose, 2011, "International Reserve Hoarding in Emerging Economies," Economic Policy Papers Central Bank of Chile, No. 40.

Dominguez, Kathryn, Yuko Hashimoto and Takatoshi Ito, "International Reserves and the Global Financial Crisis," presented at the NBER Global Financial Crisis Conference, Bretton Woods, NH, June 2011.

Eichengreen, Barry, and Ricardo Hausmann, 1999, "Exchange Rates and Financial Fragility," in New Challenges for Monetary Policy, Jackson Hole Symposium, Federal Reserve Bank of Kansas City.

Eichengreen, Barry, 2011, Exorbitant Privilege: The Rise and Fall of the Dollar and the Future of the International Monetary System, Oxford University Press.

Forbes, Kristin J. and Francis E. Warnock, 2011, “Capital Flow Waves: Surges, Stops, Flight and Retrenchment," presented at the NBER Global Financial Crisis Conference, Bretton Woods, NH, June 2011. 
Frankel, Jeffrey, and George Saravelos, 2011, "Can Leading Indicators Assess Country Vulnerability? Evidence from the 2008-09 Global Financial Crisis," Manuscript, Kennedy School of Government, Harvard University.

Gourinchas, Pierre-Olivier, and Olivier Jeanne, 2009, “Capital Flows to Developing Countries: The Allocation Puzzle," Manuscript, University of California, Berkeley and Johns Hopkins University.

Gourinchas, Pierre-Olivier, and Maurice Obstfeld, 2011, "Stories of the Twentieth Century for the Twenty-First," Prepared for the American Economic Journal:

Macroeconomics session on Financial Crises and Macroeconomics at the American Economic Association annual meeting, Denver, CO, January 8.

Gourinchas, Pierre-Olivier, Helene Rey and Kai Truempler, 2011, "The Financial Crisis and the Geography of Wealth Transfers," presented at the NBER Global Financial Crisis Conference, Bretton Woods, NH, June 2011.

International Monetary Fund, "The Fund's Role Regarding Cross-Border Capital Flows," November 2010.

International Monetary Fund, February 2011, “Assessing Reserve Adequacy.”

International Monetary Fund, Fiscal Monitor, April 2011, "Shifting Gears Tackling Challenges on the Road to Fiscal Adjustment."

International Monetary Fund, Fiscal Monitor, June 2011, "Staying the Course on Fiscal Adjustment."

Jeanne, Olivier, 2007, "International Reserves in Emerging Market Countries: Too Much of a Good Thing?" Brookings Papers on Economic Activity 1, W. C. Brainard and G. L. Perry eds., pp. 1-55 (Brookings Institution: Washington, DC).

Kose, M. Ayhan, and Eswar S. Prasad, 2010, Emerging Markets: Resilience and Growth Amid Global Turmoil, Brookings Institution Press.

Kose, M. Ayhan, Eswar S. Prasad and Marco E. Terrones, 2009, "Does Financial Globalization Promote Risk Sharing?” Journal of Development Economics, Vol. 89:2, pp. 258-270.

Kose, M. Ayhan, Eswar S. Prasad, Kenneth Rogoff, and Shang-Jin Wei, 2009, "Financial Globalization: A Reappraisal," IMF Staff Papers, Vol. 56, pp. 8-62.

Krueger, Anne O., and Jungho Yoo, 2002, "Chaebol Capitalism and the CurrencyFinancial Crisis in Korea," in Sebastian Edwards and Jeffrey Frankel, eds., Preventing Currency Crises in Emerging Markets, Cambridge, MA: National Bureau of Economic Research, pp. 601-662. 
Lane, Philip R., and Gian Maria Milesi-Ferretti, 2007, "The External Wealth of Nations Mark II: Revised and Extended Estimates of Foreign Assets and Liabilities, 19702004," Journal of International Economics, Vol. 73:2, pp. 223-250.

Lane, Philip R., and Gian-Maria Milesi-Ferretti, 2008, "The Drivers of Financial Globalization," American Economic Review (Papers and Proceedings), Vol. 98:2, pp. 327-332.

Lardy, Nicholas R., 2008, "Financial Repression in China," Policy Brief 08-8, Peterson Institute for International Economics.

Magud, E. Nicholas, Carmen Reinhart, and Kenneth Rogoff, 2011, "Capital Controls: Myth and Reality - A Portfolio Balance Approach,” Peterson Institute for International Economics Working Paper 11-7.

Mendoza, Enrique G., Vincenzo Quadrini, and José-Víctor Ríos-Rull, 2009, "Financial Integration, Financial Development, and Global Imbalances," Journal of Political Economy, Vol. 117, No. 3, pp. 371-416.

Milesi-Ferretti, Gian-Maria, Francesco Strobbe and Natalia Tamirisa, 2010, "Bilateral Financial Linkages and Global Imbalances: a View on the Eve of the Financial Crisis," IMF Working Paper 10/257.

Obstfeld, Maurice, 2010, "Expanding Gross Asset Positions and the International Monetary System," Proceedings of the 2010 Jackson Hole Symposium, Federal Reserve Bank of Kansas City.

Obstfeld, Maurice, 2011, "The SDR as an International Reserve Asset: What Future?" Manuscript, University of California, Berkeley.

Obstfeld, Maurice, and Kenneth Rogoff, 2010, "Global Imbalances and the Financial Crisis: Products of Common Causes," Prepared for the Federal Reserve Bank of San Francisco Asia Economic Policy Conference, Santa Barbara, CA, October 1820, 2009.

Obstfeld, Maurice, Jay C. Shambaugh, and Alan M. Taylor, 2010, "Financial Stability, the Trilemma, and International Reserves," American Economic Journal: Macroeconomics, Vol. 2 No. 2, pp. 57-94.

Prasad, Eswar S., Raghuram G. Rajan and Arvind Subramanian, 2007, "Foreign Capital and Economic Growth," Brookings Papers on Economic Activity, No. 1, pp. 153230 .

Prasad, Eswar S., and Raghuram Rajan, 2008, "A Pragmatic Approach to Capital Account Liberalization," Journal of Economic Perspectives, Vol. 22:3, pp. 149-172. 
Prasad, Eswar S., 2009a, “Is China's Growth Miracle Built to Last?” China Economic Review, Vol. 20, pp. 103-123.

Prasad, Eswar S., 2009b, “The Insurance Solution,” The Wall Street Journal Asia, March 11.

Prasad, Eswar S., and Mengjie Ding, 2011, "Debt Burden in Advanced Economies Now a Global Threat," Financial Times, July 31.

Rajan, Raghuram G., 2010, Fault Lines: How Hidden Fractures Still Threaten the World Economy, Princeton University Press.

Reinhart, Carmen M. and Kenneth Rogoff, 2009, This Time is Different: Eight Centuries of Financial Folly, Princeton University Press.

Ye, Lei, 2011, "Financial Integration and Wage Inequality," Manuscript in progress, Cornell University. 
Table 1. Gross External Assets and Liabilities as a Ratio to GDP

2000

219.7

226.7

Group ratio

Emerging Markets

Median

104.4

130.7

139.8

Group ratio

90.4

119.0

120.8

\section{Selected Advanced Economies}

Euro Area average

322.8

523.0

527.2

Germany

274.1

414.2

474.0

Japan

102.4

194.5

196.9

U.K.

601.0

1126.8

1308.0

U.S.

138.8

274.5

294.1

\section{Selected Emerging Markets}

Brazil

86.7

93.6

90.4

China

69.7

104.3

109.9

India

41.8

64.8

69.7

Russia

166.7

179.7

171.8

Saudi Arabia

102.6

192.0

251.3

South Africa

145.2
174.3

Data sources: IMF's International Financial Statistics and Lane-Milesi-Ferretti (2010). For the U.S., data for 2010 are from the Survey of Current Business, July 2011 (Table 1 on page 121).

Notes: Median refers to the cross-sectional median of the ratio across the countries in the group. The group ratio is the sum of external assets and liabilities for all countries in the group divided by the sum of their nominal GDPs. For a few countries, data for 2009 were used when data for 2010 were not available and data for 2001 or 2002 were used when data for 2000 were not available. Euro Area countries not included in the sample are Cyprus, Luxembourg, and Malta. 
Table 2. International Investment Positions in 2010

(in billions of U.S. dollars)

\begin{tabular}{|c|c|c|c|c|c|c|c|c|}
\hline & Germany & Japan & U.K. & U.S. & Brazil & China & India & Russia \\
\hline Net Position & 1383.1 & 3087.7 & -317.2 & -2470.9 & -698.2 & 1790.7 & -122.9 & 118 \\
\hline \multicolumn{9}{|l|}{ A. Assets } \\
\hline Total & 8550.1 & 6918.7 & 14539.4 & 20315.4 & 595.4 & 4126.0 & 380.9 & 1109.2 \\
\hline 1. FDI & 1425.8 & 831.1 & 1674.5 & 4429.4 & 175.2 & 310.8 & 77.2 & 318.7 \\
\hline 2. Portfolio & 2581.1 & 3345.8 & 3240.4 & 6222.9 & 16.6 & 257.1 & 1.2 & 38.1 \\
\hline Equity & 764.6 & 678.5 & 1158.7 & 4485.6 & 0.8 & 63.0 & 1.2 & 2.5 \\
\hline Debt & 1816.5 & 2667.4 & 2081.7 & 1737.3 & 15.8 & 194.1 & 0.0 & 35.6 \\
\hline 3. Other invst. & 3278.9 & 1592.4 & 5984.3 & 5521.5 & 114.9 & 643.9 & 19.0 & 310.7 \\
\hline 4. Resv. assets & 216.5 & 1096.7 & 77.6 & 488.7 & 288.6 & 2914.2 & 283.5 & 439.4 \\
\hline Fx reserves & 37.4 & 1036.3 & 49.3 & 51.8 & 280.6 & 2847.3 & 258.6 & 405.8 \\
\hline $\begin{array}{l}\text { 5. Fin. } \\
\text { derivatives }\end{array}$ & 1047.8 & 52.6 & 3562.7 & 3652.9 & 0.2 & 0.0 & 0.0 & 2.3 \\
\hline \multicolumn{9}{|l|}{ B. Liabilities } \\
\hline Total & 7167.0 & 3831.0 & 14856.6 & 22786.3 & 1293.7 & 2335.4 & 503.8 & 990.8 \\
\hline 1. FDI & 956.6 & 214.9 & 1075.9 & 2658.9 & 472.6 & 1476.4 & 164.0 & 382.5 \\
\hline 2. Portfolio & 3019.7 & 1871.7 & 3939.0 & 7266.8 & 656.3 & 221.6 & 117.1 & 216.4 \\
\hline Equity & 590.2 & 988.8 & 1471.6 & 2991.6 & 430.2 & 206.1 & 93.3 & 173.0 \\
\hline Debt & 2429.6 & 882.9 & 2467.3 & 9138.8 & 226.1 & 15.5 & 23.8 & 43.4 \\
\hline 3. Other invst. & 2139.8 & 1679.7 & 6374.9 & 4454.5 & 161.0 & 637.3 & 222.8 & 385.2 \\
\hline $\begin{array}{l}\text { 4. Fin. } \\
\text { derivatives }\end{array}$ & 1050.8 & 64.7 & 3466.9 & 3542.5 & 3.8 & 0.0 & 0.0 & 6.8 \\
\hline
\end{tabular}

Data sources: IMF's International Financial Statistics and U.S. Survey of Current Business.

Notes: Data for Brazil, China, Japan, Germany, U.K. and the U.S. are for the year 2010, and data for India and Russia are for the year 2009. 
Table 3. Structure of External Liabilities and Assets

\begin{tabular}{|c|c|c|c|c|c|c|c|c|c|c|c|c|}
\hline & \multicolumn{3}{|c|}{ FDI/Tot. Liab. } & \multicolumn{3}{|c|}{$\begin{array}{l}\text { Portf. Equity/ } \\
\text { Tot. Liab. }\end{array}$} & \multicolumn{3}{|c|}{$\begin{array}{l}(\mathrm{FDI}+\mathrm{PE}) / \\
\text { Tot. Liab. }\end{array}$} & \multicolumn{3}{|c|}{$\begin{array}{c}\text { FX Reserves/ } \\
\text { Tot. Assets }\end{array}$} \\
\hline & 2000 & 2007 & 2010 & 2000 & 2007 & 2010 & 2000 & 2007 & 2010 & 2000 & 2007 & 2010 \\
\hline \multicolumn{13}{|c|}{ Advanced Economies } \\
\hline Median & 20.0 & 18.4 & 19.7 & 15.0 & 13.8 & 9.9 & 40.3 & 38.6 & 31.4 & 5.8 & 1.9 & 1.2 \\
\hline Group ratio & 17.5 & 15.3 & 14.9 & 21.6 & 16.3 & 13.6 & 39.1 & 31.6 & 28.5 & 3.7 & 2.5 & 3.0 \\
\hline \multicolumn{13}{|l|}{ Emerging Markets } \\
\hline Median & 31.8 & 39.4 & 40.5 & 3.7 & 8.4 & 8.2 & 34.4 & 56.7 & 56.2 & 34.6 & 43.7 & 38.8 \\
\hline Group ratio & 33.0 & 42.0 & 46.4 & 7.4 & 18.8 & 14.5 & 40.4 & 60.8 & 60.9 & 31.7 & 49.9 & 52.7 \\
\hline \multicolumn{13}{|c|}{ Selected Advanced Economies } \\
\hline Euro Area average & 17.7 & 17.0 & 15.5 & 20.2 & 15.8 & 12.4 & 38.0 & 32.7 & 27.9 & 2.1 & 0.7 & 0.7 \\
\hline Germany & 17.9 & 15.8 & 13.3 & 11.7 & 13.8 & 8.2 & 29.6 & 29.6 & 21.6 & 1.9 & 0.6 & 0.4 \\
\hline Japan & 2.8 & 4.2 & 5.6 & 30.4 & 39.4 & 25.8 & 33.1 & 43.6 & 31.4 & 11.7 & 17.7 & 15.0 \\
\hline U.K. & 10.2 & 7.6 & 7.2 & 22.2 & 10.4 & 9.9 & 32.5 & 18.0 & 17.1 & 0.8 & 0.3 & 0.3 \\
\hline U.S. & 18.8 & 11.9 & 11.7 & 21.7 & 16.0 & 13.1 & 40.4 & 27.9 & 24.8 & 0.5 & 0.2 & 0.3 \\
\hline \multicolumn{13}{|c|}{ Selected Emerging Markets } \\
\hline Brazil & 32.8 & 33.6 & 36.5 & 9.9 & 39.6 & 33.3 & 42.7 & 73.2 & 69.8 & 33.2 & 48.5 & 47.1 \\
\hline China & 59.4 & 57.3 & 63.2 & 5.7 & 5.6 & 8.8 & 61.4 & 66.3 & 65.6 & 37.6 & 63.3 & 69.0 \\
\hline India & 14.7 & 25.8 & 32.5 & 12.6 & 24.8 & 18.5 & 27.2 & 50.5 & 51.1 & 59.8 & 79.4 & 67.9 \\
\hline Russia & 17.5 & 39.5 & 38.6 & 6.0 & 24.9 & 17.5 & 23.5 & 64.4 & 56.1 & 9.8 & 42.7 & 36.6 \\
\hline Saudi Arabia & 54.1 & 52.8 & 60.0 & 0.0 & 3.8 & 3.5 & 54.1 & 56.7 & 63.5 & 13.8 & 53.9 & 56.0 \\
\hline South Africa & 43.5 & 39.0 & 41.5 & 22.6 & 38.9 & 35.0 & 66.1 & 77.9 & 76.5 & 6.2 & 13.6 & 13.4 \\
\hline
\end{tabular}

Data sources: IMF's International Financial Statistics, Lane-Milesi-Ferretti (2010) and U.S. Survey of Current Business.

Notes: Median refers to the cross-sectional median of the ratio across the countries in the group. The group ratio is the sum of the numerator variable for all countries in the group divided by the sum of the denominator variable for those countries. Economies not included in "Euro Area" are Cyprus, Luxembourg, and Malta. For some economies, 2009 data are used whenever 2010 data are not available, and 2001 or 2002 data are used whenever 2000 data are not available. 
Table 4. Changes in Structure of Emerging Markets' External Portfolios: 2000-07

\begin{tabular}{|c|c|c|c|c|}
\hline & & A. Liabilities & & B. Assets \\
\hline & $\begin{array}{c}\text { Change in } \\
\text { FDI Liabs. / } \\
\text { Change in } \\
\text { Total Liabs. }\end{array}$ & $\begin{array}{r}\text { Change in Port. Eq. } \\
\text { Liabs. / Change in } \\
\text { Total Liabs. }\end{array}$ & $\begin{array}{r}\text { Change in } \\
\text { FDI+PE Liabs. / } \\
\text { Change in Total } \\
\text { Liabs. }\end{array}$ & $\begin{array}{r}\text { Change in Fx } \\
\text { Reserves / Chg. } \\
\text { in Total Assets }\end{array}$ \\
\hline Argentina & -0.5 & -7.5 & -7.1 & 37.2 \\
\hline Brazil & 34.2 & 59.7 & 93.9 & 54.7 \\
\hline Bulgaria & 67.8 & 1.7 & 69.5 & 66.1 \\
\hline Chile & 65.7 & 5.5 & 71.2 & 1.7 \\
\hline China & 56.3 & 13.7 & 70.0 & 69.0 \\
\hline Colombia & 79.7 & 2.6 & 82.3 & 37.4 \\
\hline Hungary & 59.6 & 4.2 & 63.9 & 6.7 \\
\hline India & 31.4 & 31.0 & 62.4 & 83.9 \\
\hline Indonesia & 58.4 & 33.3 & 91.7 & 50.0 \\
\hline Jordan & 65.7 & 19.9 & 85.5 & 47.9 \\
\hline Kazakhstan & 32.5 & 9.5 & 42.0 & 19.4 \\
\hline Kenya & 60.2 & 7.5 & 67.6 & 51.8 \\
\hline Latvia & 21.3 & 0.8 & 22.1 & 22.7 \\
\hline Lithuania & 35.4 & 1.7 & 37.1 & 37.9 \\
\hline Malaysia & 31.3 & 41.6 & 72.8 & 43.5 \\
\hline Mexico & 52.6 & 37.8 & 90.3 & 39.8 \\
\hline Morocco & 81.4 & 8.2 & 89.6 & 69.4 \\
\hline Nigeria & 122.9 & 53.3 & 176.2 & 72.9 \\
\hline Pakistan & 59.4 & 8.2 & 67.6 & 78.0 \\
\hline Peru & 42.0 & 44.8 & 86.9 & 55.6 \\
\hline Philippines & 25.9 & 34.1 & 60.0 & 46.3 \\
\hline Poland & 48.2 & 9.2 & 57.5 & 32.5 \\
\hline Romania & 48.3 & 1.6 & 49.9 & 77.9 \\
\hline Russia & 43.3 & 28.1 & 71.5 & 52.4 \\
\hline Saudi Arabia & 52.1 & 6.0 & 58.1 & 65.9 \\
\hline South Africa & 36.5 & 47.8 & 84.3 & 19.3 \\
\hline Thailand & 61.7 & 46.9 & 108.5 & 48.4 \\
\hline Turkey & 40.9 & 17.2 & 58.1 & 44.5 \\
\hline Ukraine & 36.5 & 1.4 & 38.0 & 38.0 \\
\hline Median & 48.3 & 9.5 & 69.5 & 47.9 \\
\hline Group ratio & 47.1 & 25.2 & 72.3 & 56.1 \\
\hline Group ratio ex. China & 45.3 & 27.4 & 72.7 & 48.7 \\
\hline
\end{tabular}

Data sources: IMF's International Financial Statistics and Lane-Milesi-Ferretti (2010).

Notes: The first column shows the change in the stock of a country's FDI liabilities from 2000 to 2007 as a ratio of the change in that country's total external liabilities over the same period. The group ratio is the sum of the numerator variable for all countries in the group divided by the sum of the denominator variable for those countries. 
Table 5. Foreign Exchange Reserve Losses During the Crisis for Selected Economies

\begin{tabular}{|c|c|c|c|c|c|c|c|}
\hline & $\begin{array}{l}\text { High } \\
\text { level }\end{array}$ & $\begin{array}{l}\text { Low } \\
\text { level }\end{array}$ & $\begin{array}{r}\text { High } \\
\text { month }\end{array}$ & $\begin{array}{r}\text { Low } \\
\text { month }\end{array}$ & $\begin{array}{r}\text { Percent } \\
\text { drop }\end{array}$ & $\begin{array}{r}\text { No. of. } \\
\text { months: } \\
\text { high to } \\
\text { low }\end{array}$ & $\begin{array}{l}\text { Apr. } \\
2011 \\
\text { level }\end{array}$ \\
\hline Brazil & 206 & 186 & Sep-08 & Feb-09 & 9.6 & 5 & 312 \\
\hline Bulgaria & 20 & 14 & Sep-08 & Jan-09 & 30.6 & 4 & 15 \\
\hline India & 305 & 239 & May- 08 & Nov- 08 & 21.7 & 6 & 282 \\
\hline Indonesia & 58 & 48 & Jul-08 & Feb-09 & 17.5 & 7 & 107 \\
\hline Malaysia & 125 & 87 & Jun-08 & Mar-09 & 30.6 & 9 & 118 \\
\hline Mexico & 98 & 79 & Sep-08 & Aug-09 & 19.0 & 11 & 120 \\
\hline Nigeria & 62 & 42 & Sep-08 & Aug-09 & 32.7 & 11 & 33 \\
\hline Peru & 35 & 28 & Jun-08 & Feb-09 & 18.5 & 8 & 42 \\
\hline Poland & 82 & 56 & Jul-08 & Jan-09 & 31.6 & 6 & 95 \\
\hline Russia & 582 & 367 & Jul-08 & Feb-09 & 37.0 & 7 & 463 \\
\hline South Korea & 264 & 200 & Mar-08 & Nov-08 & 24.3 & 8 & 303 \\
\hline Turkey & 76 & 64 & Sep-08 & Apr-09 & 16.0 & 7 & 88 \\
\hline Ukraine & 37 & 24 & Sep-08 & Apr-09 & 36.5 & 7 & 37 \\
\hline Median & & & & & 27.4 & 7 & \\
\hline
\end{tabular}

Data source: IMF's International Financial Statistics, CEIC.

Notes: This table shows the recent peak and trough of a country's stock of foreign exchange reserves during the financial crisis. Absolute levels of reserves are in billions of U.S. dollars. The economies selected for this table are relatively large emerging markets (along with South Korea) that experienced significant reserve losses. 


\section{Figure 1. Uphill Capital Flows: Current Account Balances}

\section{A. Ratio to GDP (in percent)}

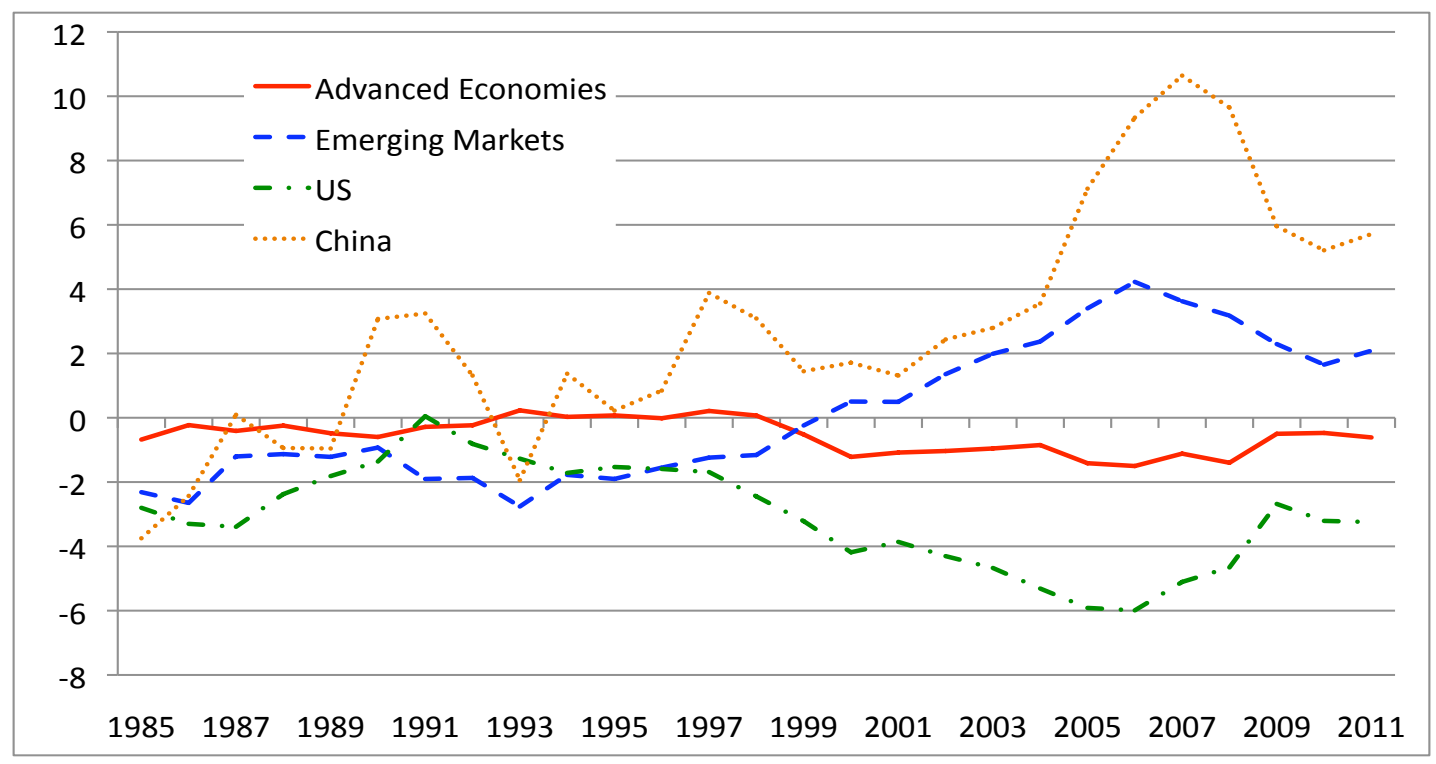

B. Levels (in billions of U.S. dollars)

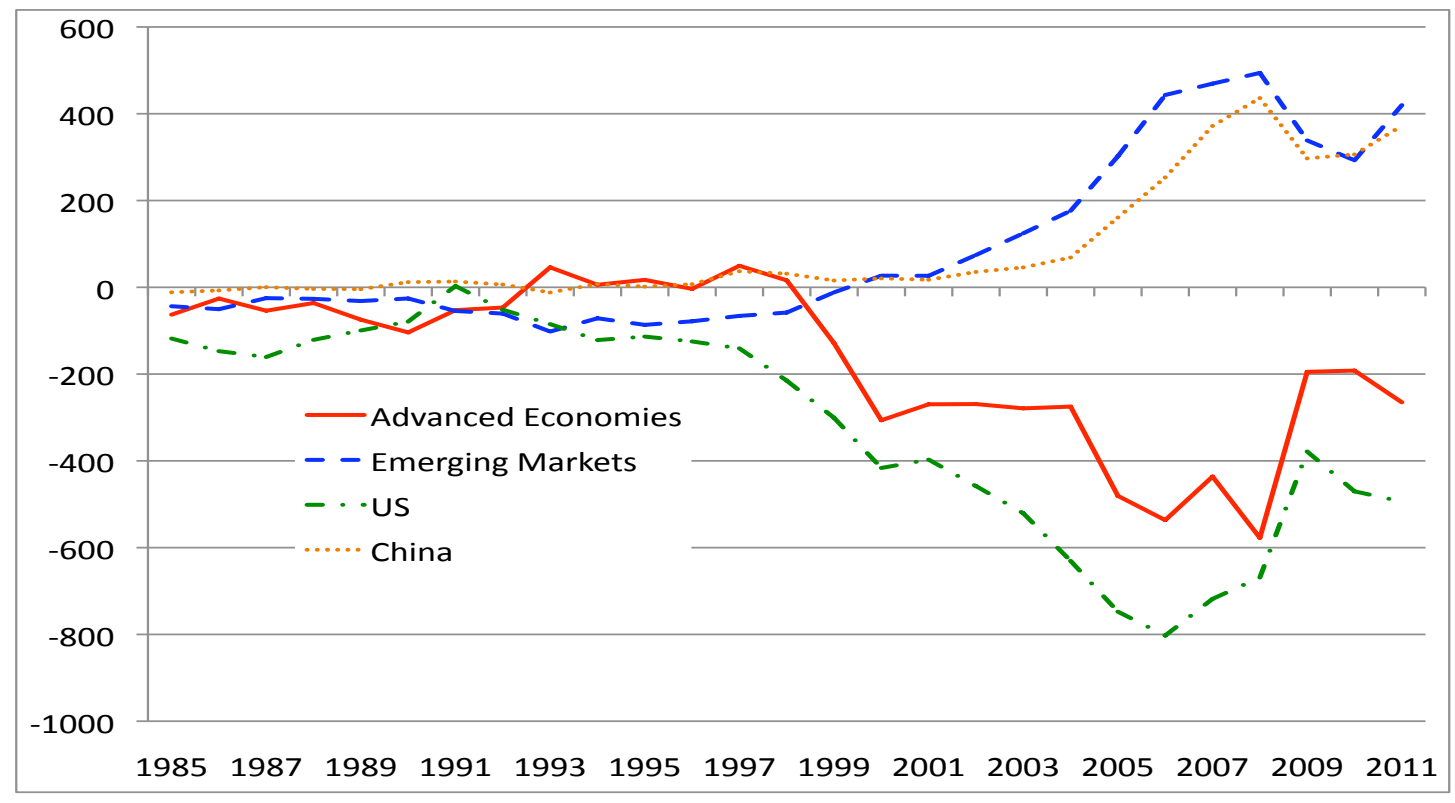

Data source: IMF's World Economic Outlook

Notes: The aggregate numbers in this figure are based on a sample that includes 29 advanced and 29 emerging market economies, which are listed in the Appendix. The aggregate ratios for each group of countries are obtained by adding up all current account balances (in U.S. dollars) and dividing by the sum of their nominal GDPs (in U.S. dollars). Data for 2011 are based on IMF forecasts. 


\section{Figure 2. Rising Financial Openness}

A. Advanced Economies

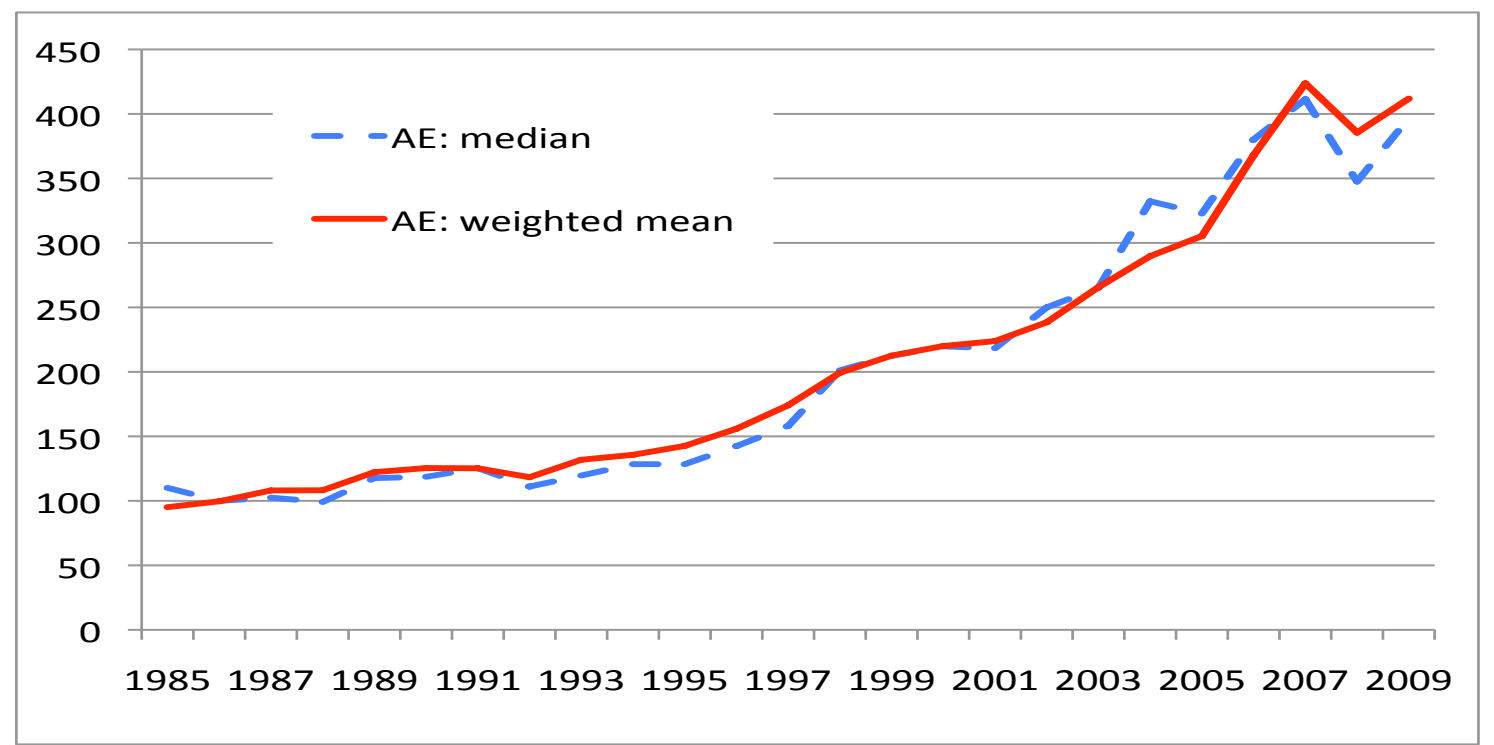

B. Emerging Market Economies

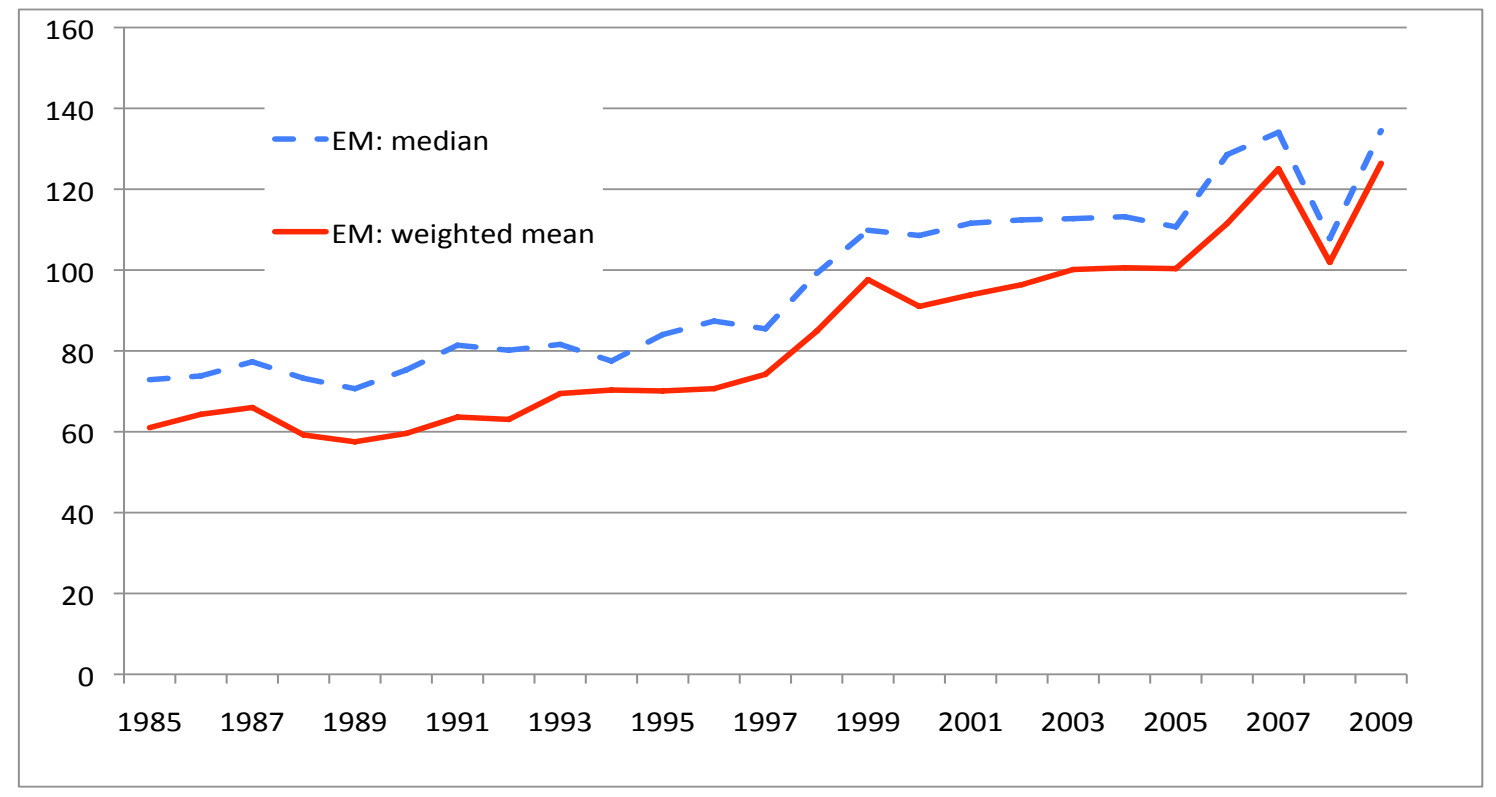

Data source: Lane and Milesi-Ferretti (2010)

Notes: Financial openness is defined as the sum of gross external assets and gross external liabilities expressed as a ratio to nominal GDP, with all variables measured in current price U.S. dollars at market exchange rates. The median is the cross-sectional median calculated separately for each year for the relevant group of countries. The weighted mean is the ratio of the sum of external assets and liabilities for all countries in the group expressed as a ratio of the sum of nominal GDP for all countries in that group. 
Figure 3. Key Components of Emerging Market External Assets and Liabilities

\section{A. Weighted Means}

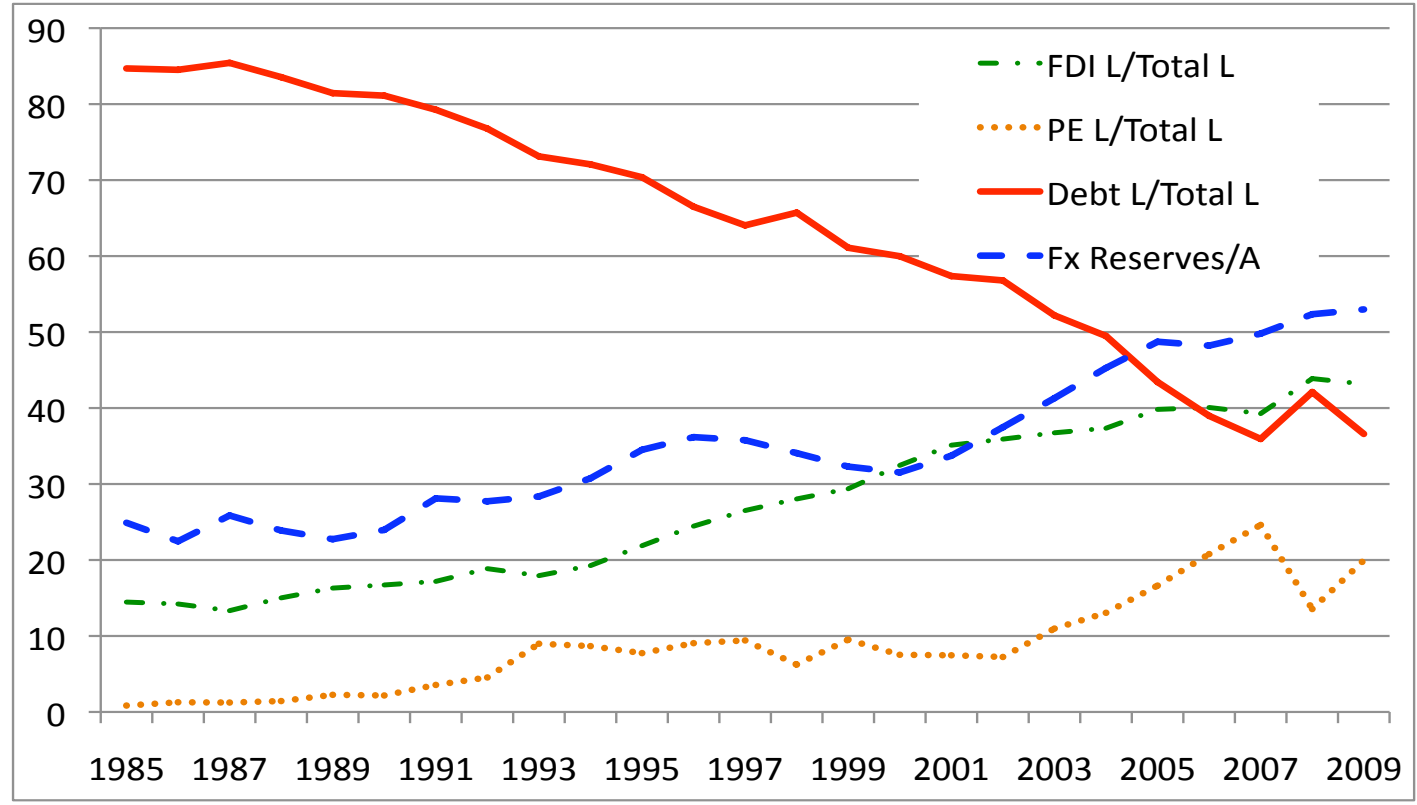

B. Medians

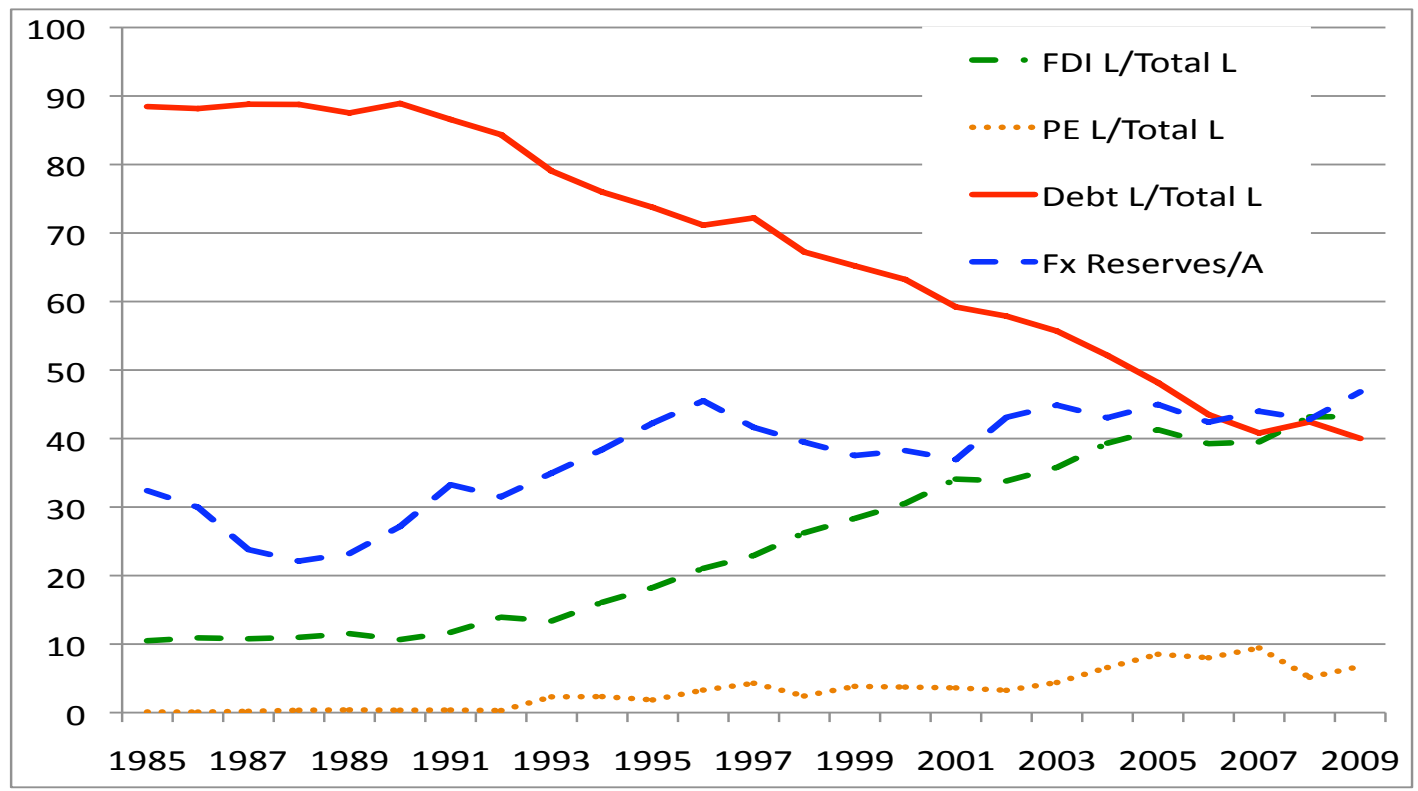

Data source: Lane and Milesi-Ferretti (2010)

Notes: Stocks of foreign direct investment (FDI), portfolio equity (PE) and external debt are shown as ratios of total external liabilities (L). The stock of foreign exchange reserves is shown as a ratio to total external assets (A). The median is the cross-sectional median calculated separately for each year for the relevant group of countries. The weighted mean is the ratio of the sum of external assets and liabilities for all countries in the group expressed as a ratio of the sum of nominal GDP for all countries in that group. 
Figure 4. Reserve Accumulation by Emerging Markets

(in billions of U.S. dollars)

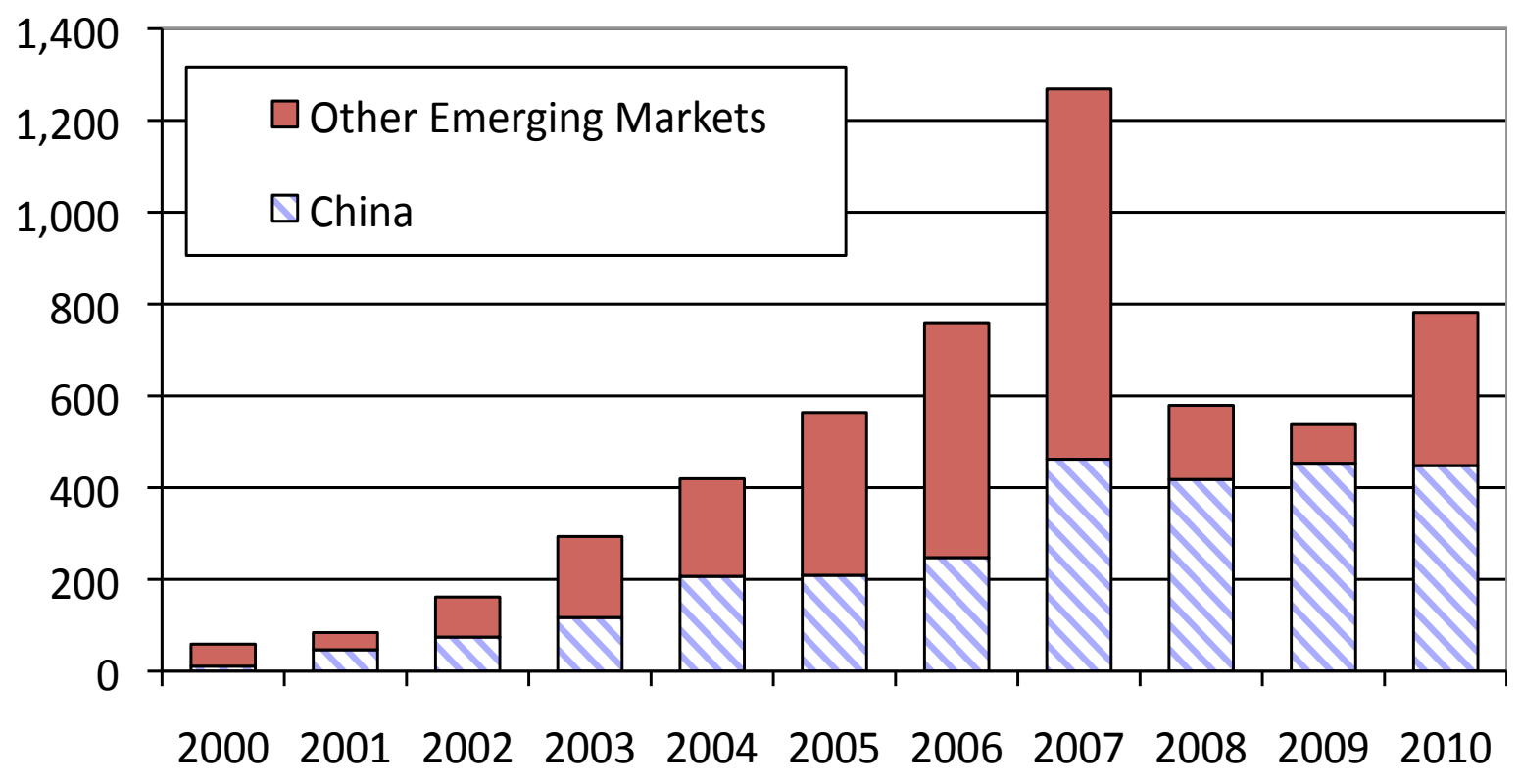

Data sources: IMF COFER Database, June 30, 2011; The People's Bank of China 
Figure 5. Foreign Exchange Reserves Held by Emerging Markets

A. Total Foreign Exchange Reserves (trillions USD)

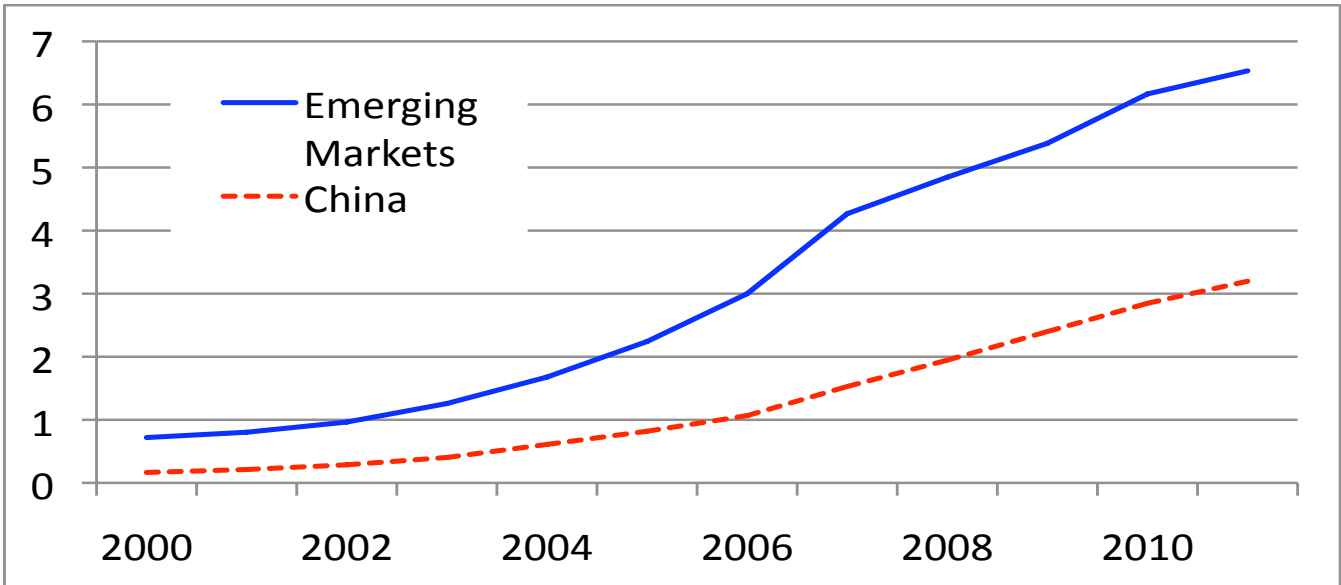

B. Currency Composition

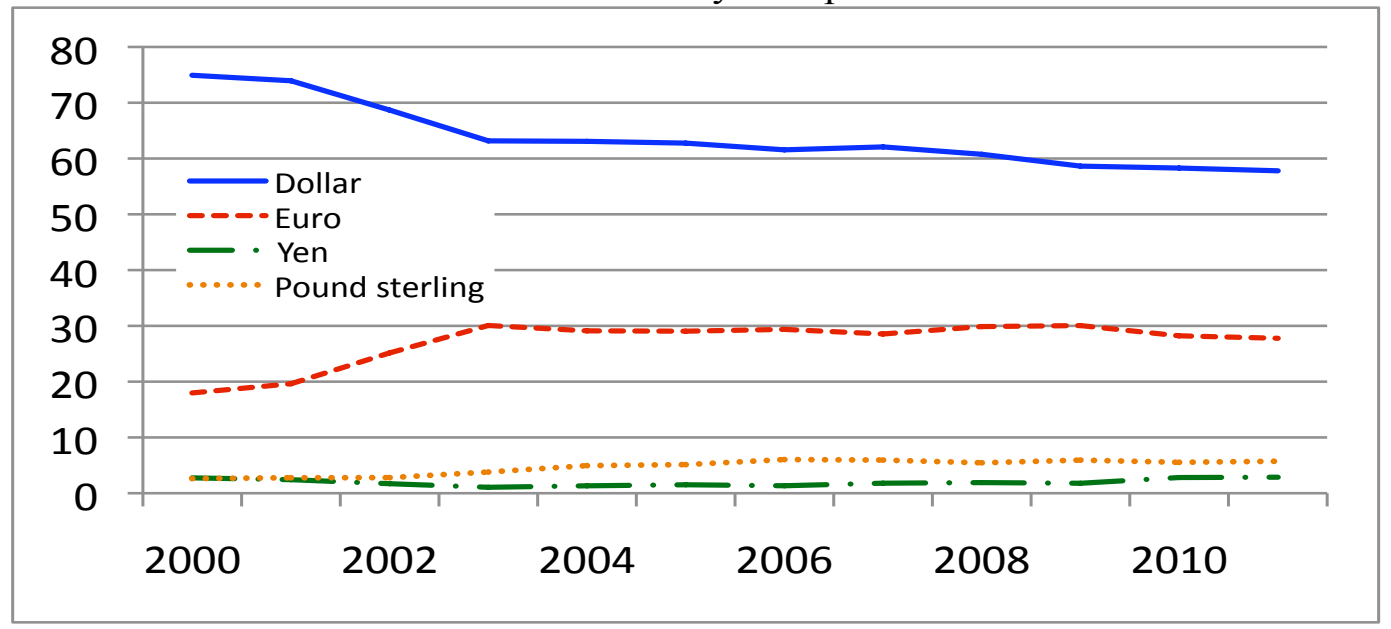

C. Share of Reserves for Which Currency Composition is Known

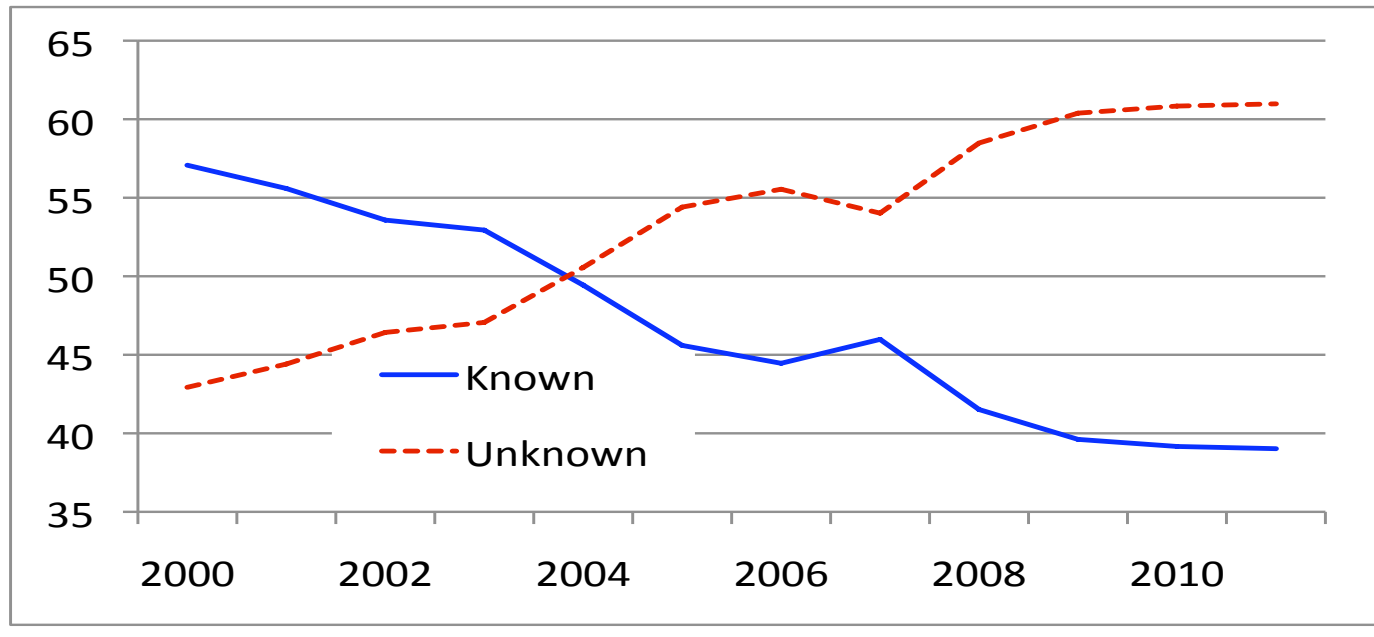

Data sources: IMF COFER Database, June 30, 2011; The People's Bank of China 


\section{Figure 6. World Government Debt}

\section{A. Aggregate Debt (in trillions of U.S. dollars)}

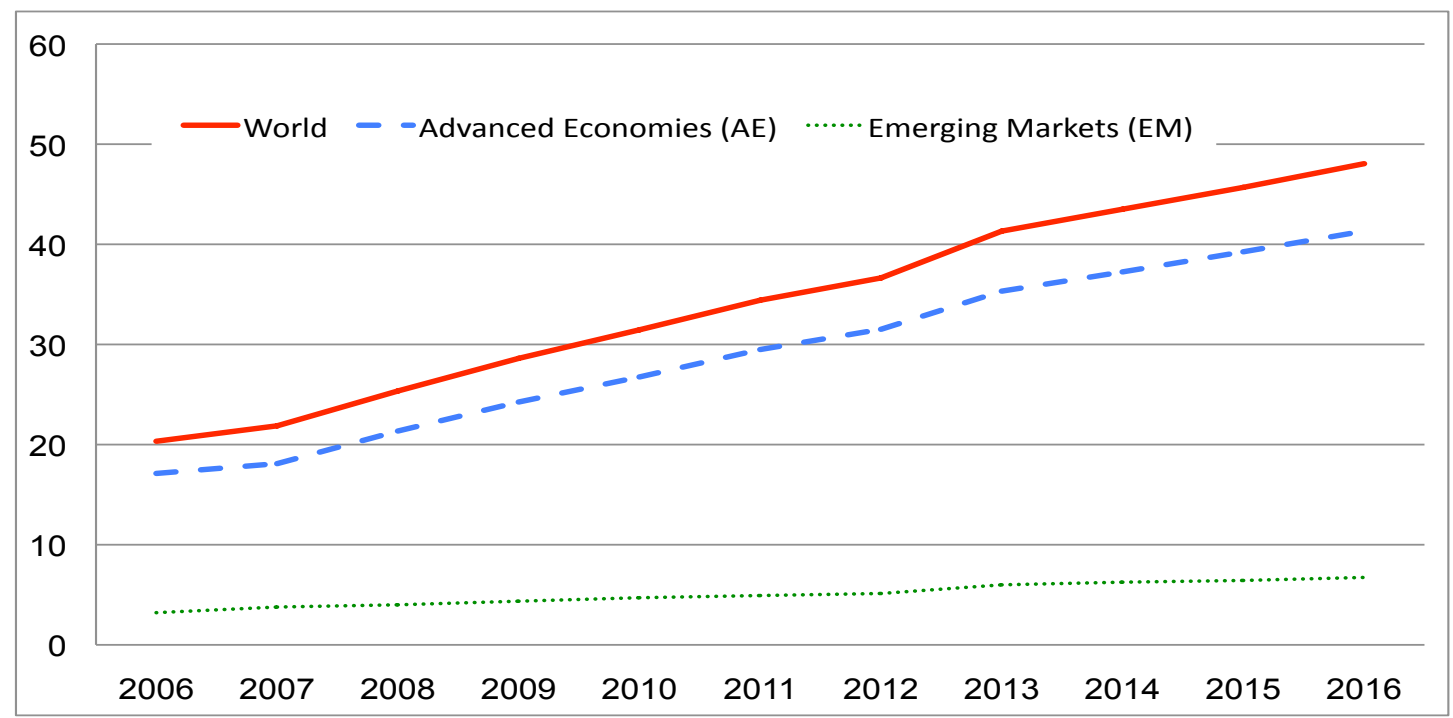

Ratio of Aggregate Debt to Aggregate GDP (in percent)

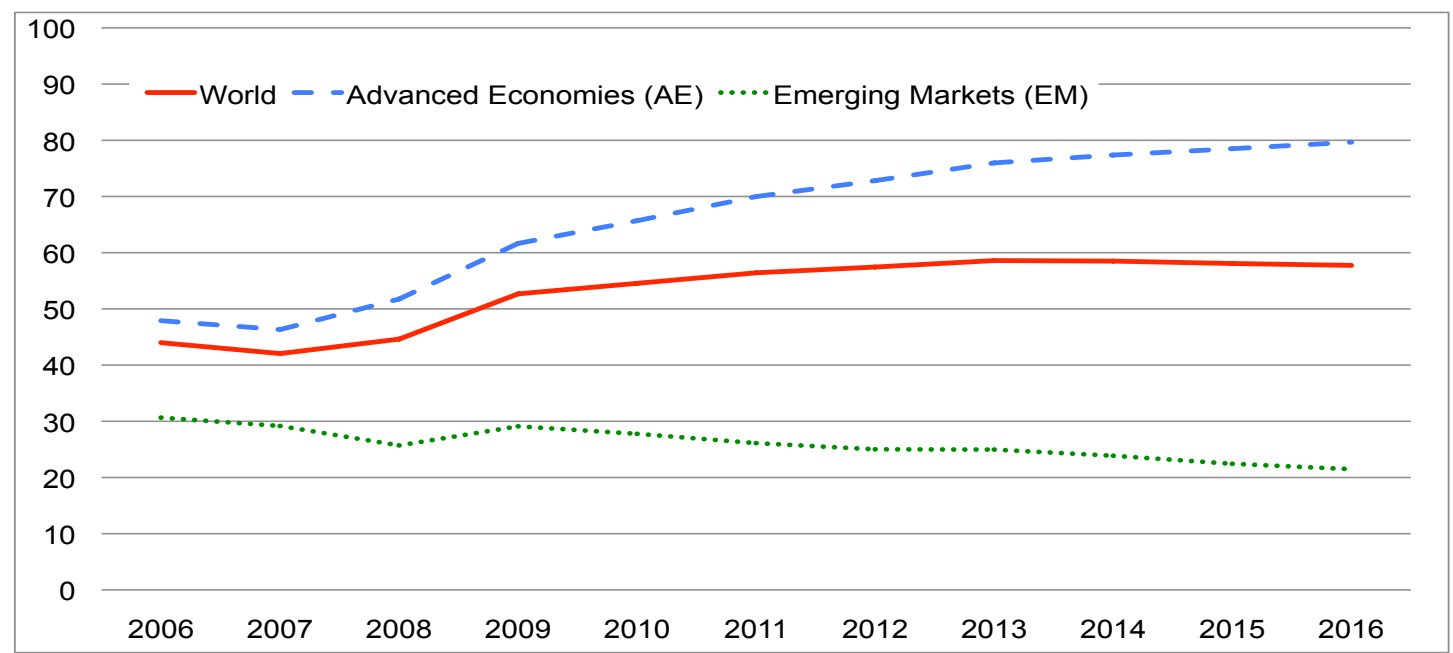

Data sources: IMF's Fiscal Monitor, International Financial Statistics and World Economic Outlook

Notes: This figure shows the aggregate level of general government debt (upper panel) and the ratio of this variable to aggregate world GDP (lower panel), with all variables converted to U.S. dollars at market exchange rates. In the upper panel, the data for advanced and emerging market economies add up to the world aggregates. In the lower panel, aggregate debt is expressed as a ratio of aggregate GDP for the respective group of countries. Net debt is used except for the following countries that report only gross debt data: Advanced Economies -- Czech Republic, Greece, Hong Kong SAR, Singapore, Slovak Republic and Slovenia; Emerging Market Economies -- Argentina, China, India, Indonesia, Malaysia, Pakistan, Peru, Philippines, Romania, Russia and Thailand. 


\section{Figure 7. Global Distribution of GDP}
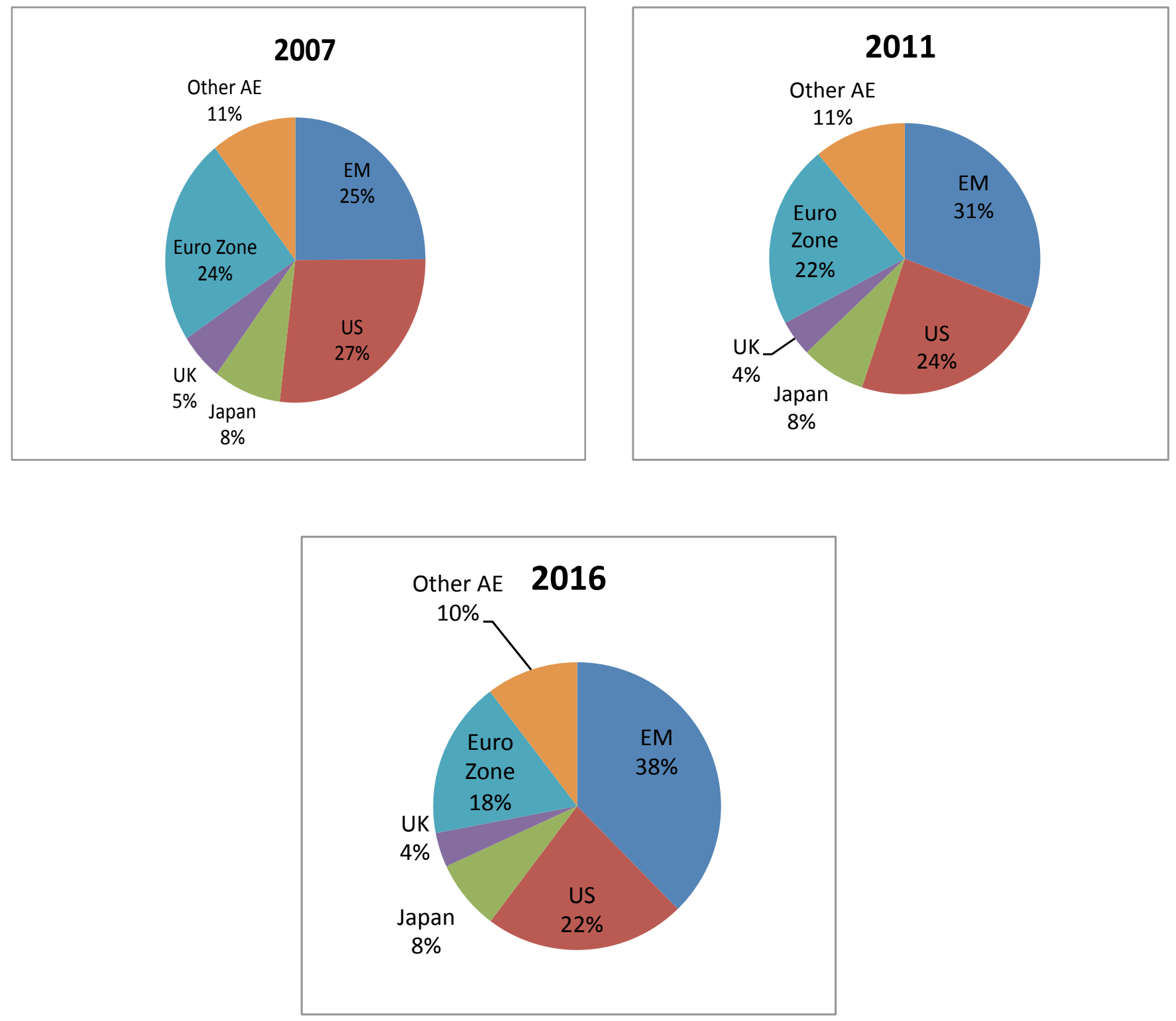

Data sources: IMF's Fiscal Monitor, International Financial Statistics and World Economic Outlook

Notes: Other AE denotes other advanced economies and EM stands for emerging markets. GDP is measured at current prices and converted to a common currency at market exchange rates. 
Figure 8. Global Distribution of Net Government Debt
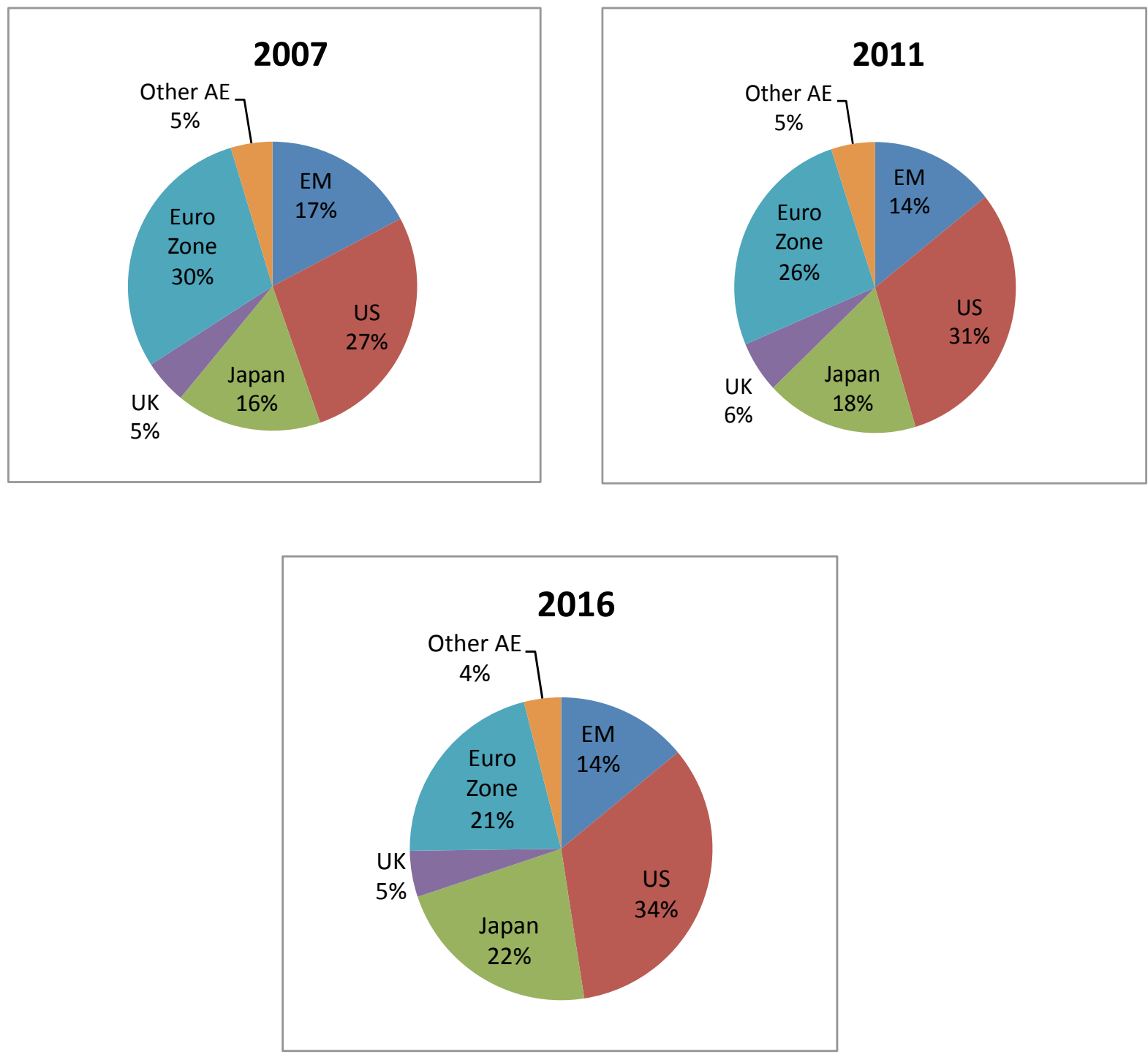

Data sources: IMF's Fiscal Monitor, International Financial Statistics and World Economic Outlook

Notes: Other AE denotes other advanced economies and EM stands for emerging markets. Net debt is used except for the following countries that report only gross debt data: Advanced Economies -- Czech Republic, Greece, Hong Kong SAR, Singapore, Slovak Republic and Slovenia; Emerging Market Economies -- Argentina, China, India, Indonesia, Malaysia, Pakistan, Peru, Philippines, Romania, Russia and Thailand. 
Figure 9. Contributions of Different Economic Areas to

Changes in Global Public Debt and GDP

A. Global Public Debt
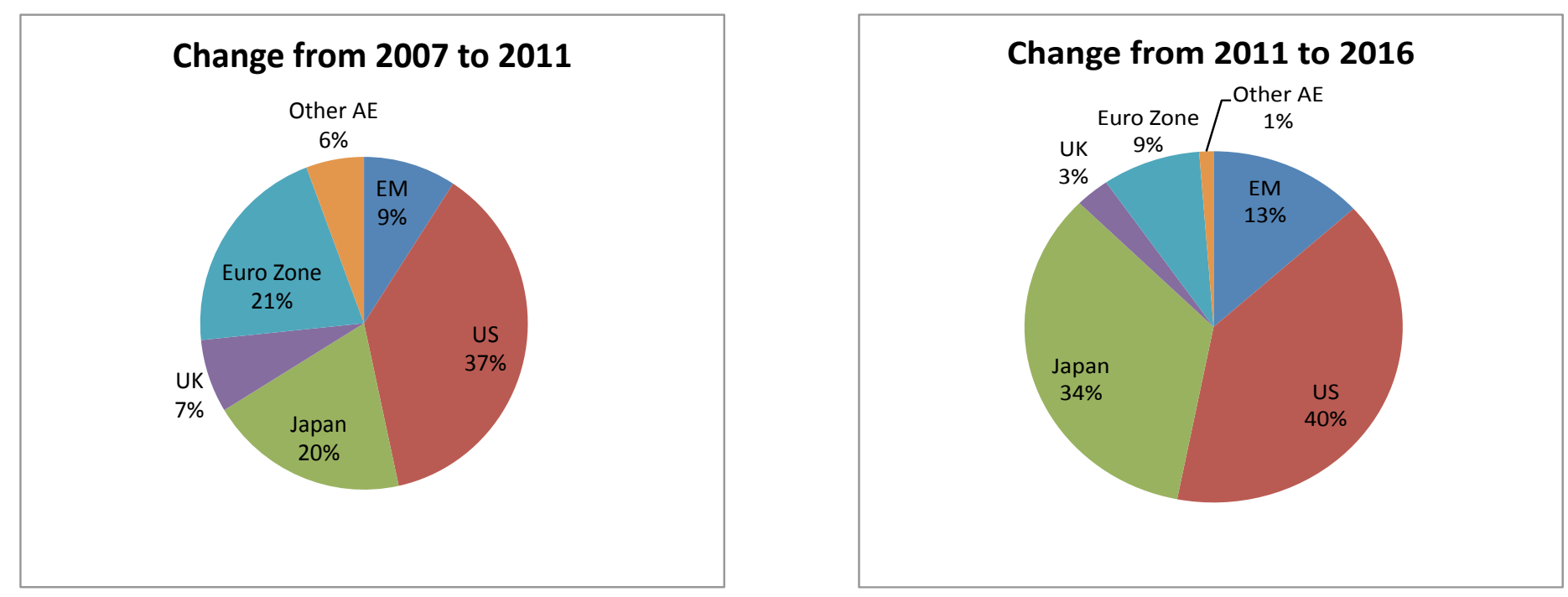

\section{B. Global GDP}
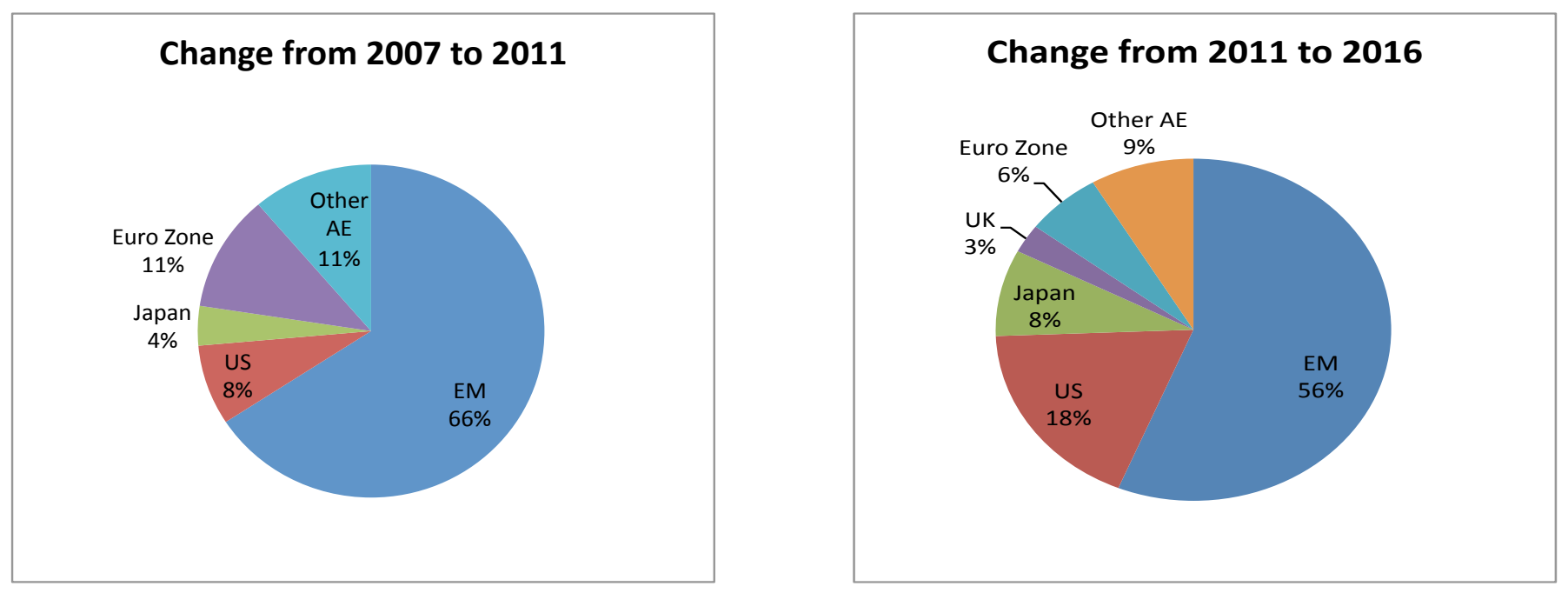

Data sources: IMF's Fiscal Monitor, International Financial Statistics and World Economic Outlook

Notes: These charts show the contributions of different countries/ country groups to the changes in the absolute levels of world net government debt and the absolute levels of world GDP (measured in a common currency at market exchange rates). Net debt is used except for the following countries that report only gross debt data: Advanced Economies -- Czech Republic, Greece, Hong Kong SAR, Singapore, Slovak Republic and Slovenia; Emerging Market Economies -- Argentina, China, India, Indonesia, Malaysia, Pakistan, Peru, Philippines, Romania, Russia and Thailand. 
Figure 10. Central Government Debt of Major Reserve Currency Economic Areas

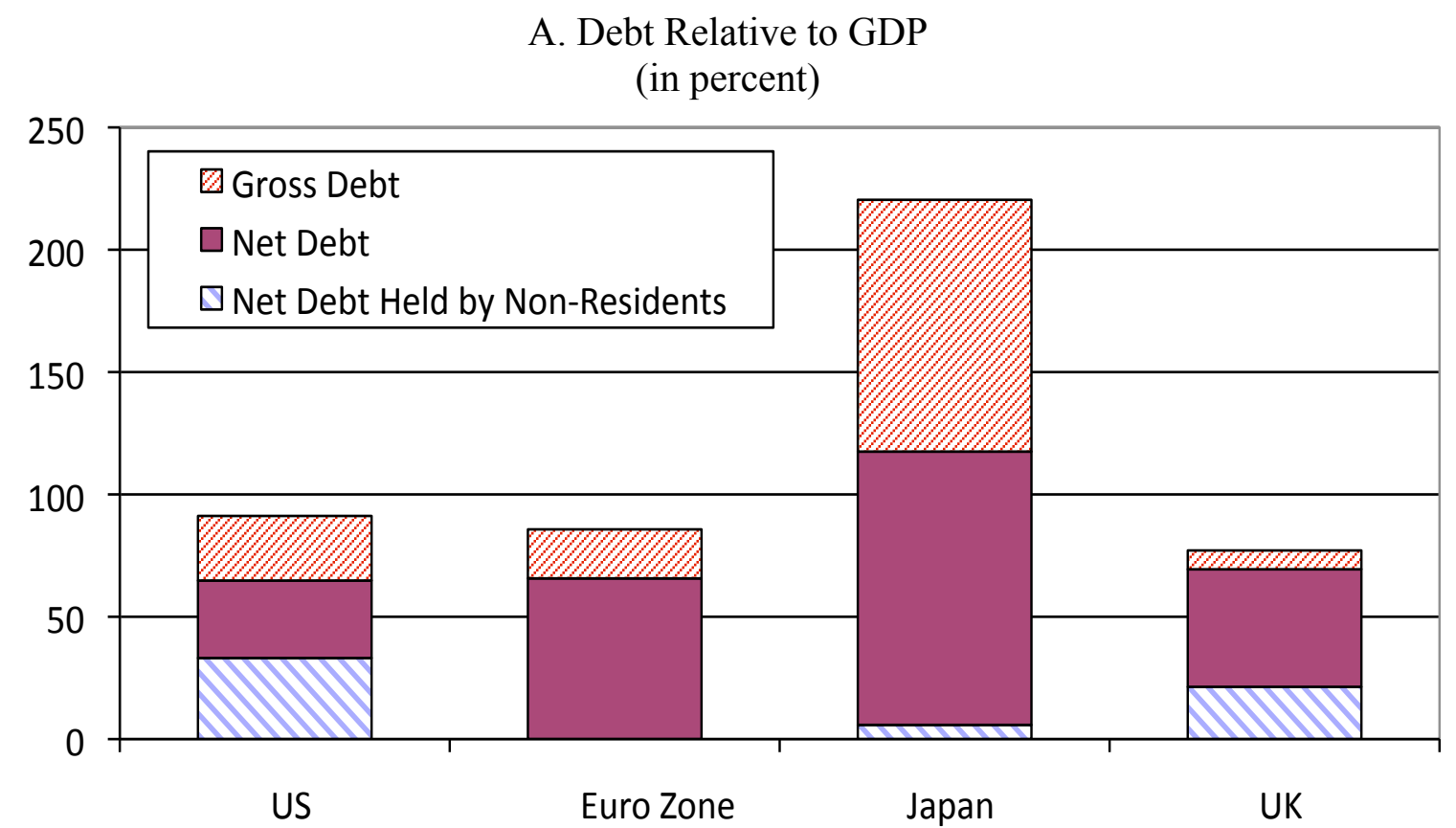

B. Absolute Levels of Debt (in trillions of U.S. dollars)

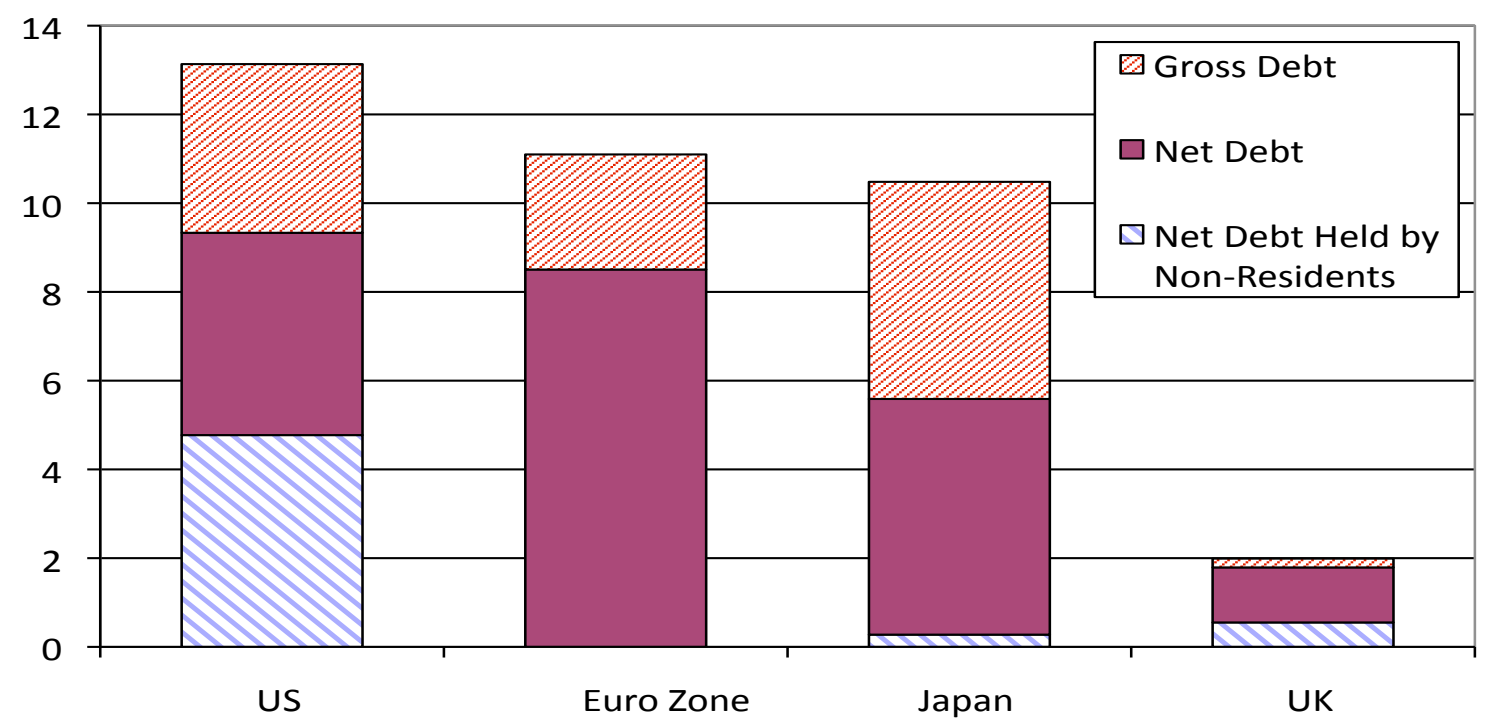

Data sources: EIU and IMF Fiscal Monitor, April and June 2011 Update; IMF WEO, April and June 2011 Update.

Notes: Data were not available on net debt of the Euro Zone countries held by investors from outside the Euro Zone. 
Figure 11. Foreign Financing of U.S. Treasury Debt Buildup (in billions of U.S. dollars)

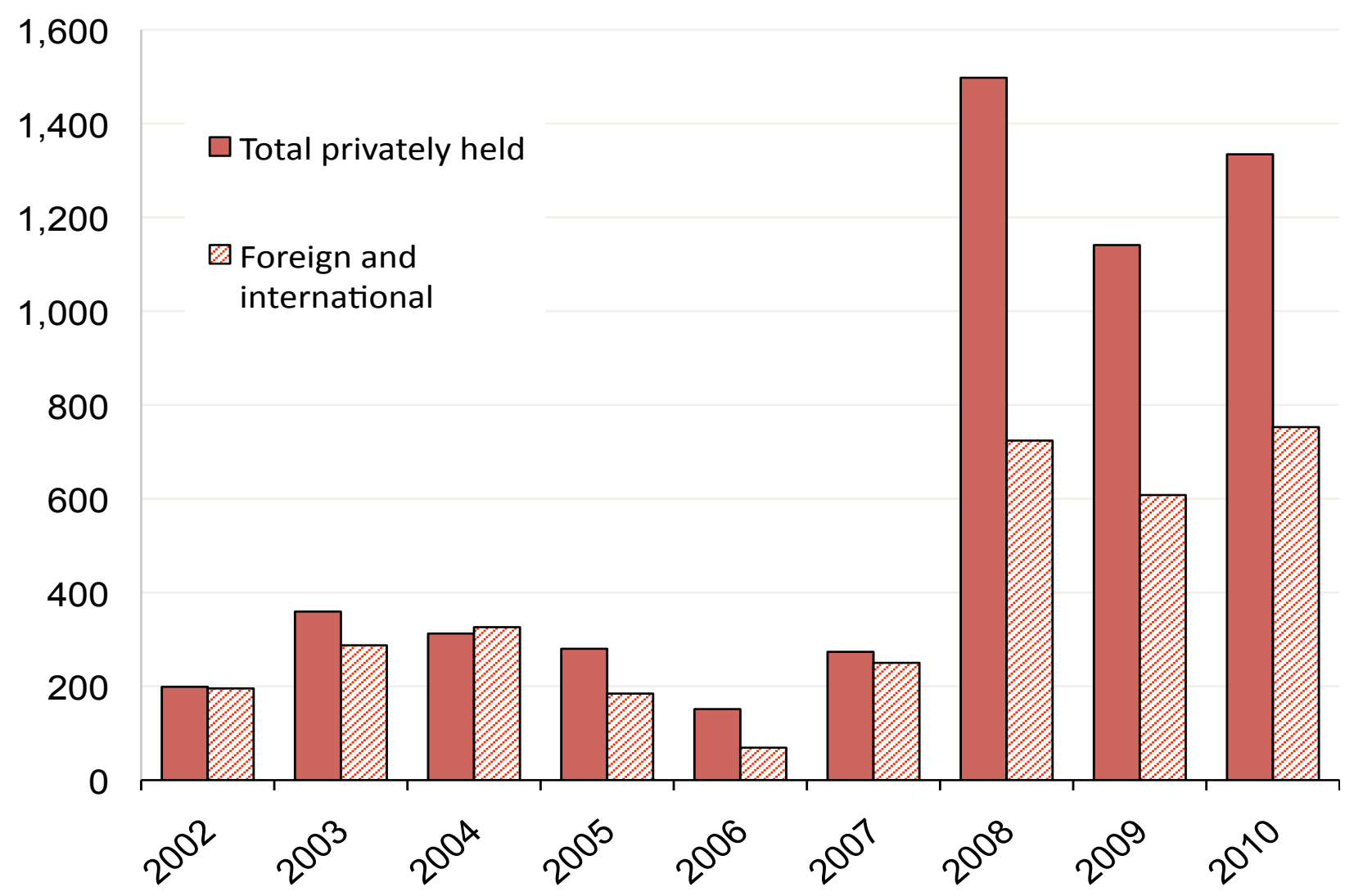

Data source: Treasury Bulletin, June 2011 Issue, United States Treasury.

Notes: Each bar denotes increases in net debt-total level and the level accounted for by foreign investors - calculated as the year to year change in end-of-year debt stocks (as reported in series (3) and (11) in Table OFS-2 on p. 41 of data source). 